\title{
The Link between Default and Recovery Rates: Implications for Credit Risk Models and Procyclicality
}

\author{
Edward I. Altman*, Brooks Brady**, Andrea Resti*** and Andrea Sironi****
}

July 2002

\begin{abstract}
This paper analyzes the impact of various assumptions about the association between aggregate default probabilities and the loss given default on bank loans and corporate bonds, and seeks to empirically explain this critical relationship. Moreover, it simulates the effects on mandatory capital requirements like those proposed in 2001 by the Basel Committee on Banking Supervision. We present the analysis and results in four distinct sections. The first section examines the literature of the last three decades of the various structuratform, closed-form and other credit risk and portfolio credit value-at-risk (VaR) models and the way they explicitly or implicitly treat the recovery rate variable. Section 2 presents simulation results under three different recovery rate scenarios and examines the impact of these scenarios on the resulting risk measures: our results show a significant increase in both expected and unexpected losses when recovery rates are stochastic and negatively correlated with default probabilities. In Section 3, we empirically examine the recovery rates on corporate bond defaults, over the period 1982-2000. We attempt to explain recovery rates by specifying a rather straightforward statistical least squares regression model. The central thesis is that aggregate recovery rates are basically a function of supply and demand for the securities. Our econometric univariate and multivariate time series models explain a significant portion of the variance in bond recovery rates aggregated across all seniority and collateral levels. Finally, in Section 4 we analyze how the link between default probability and recovery risk would affect the procyclicality effects of the New Basel Capital Accord, due to be released in 2002. We see that, if banks use their own estimates of LGD (as in the "advanced" IRB approach), an increase in the sensitivity of banks' LGD due to the variation in PD over economic cycles is likely to follow. Our results have important implications for just about all portfolio credit risk models, for markets which depend on recovery rates as a key variable (e.g., securitizations, credit derivatives, etc.), for the current debate on the revised BIS guidelines for capital requirements on bank credit assets, and for investors in corporate bonds of all credit qualities.
\end{abstract}

Keywords: credit rating, capital requirements, credit risk, recovery rate, default, procyclicality

\section{JEL Classification Numbers: G15, G21, G28}

This paper is a synthesis and analysis from the Report prepared for the International Swaps and Derivatives' Dealers Association (ISDA). The authors wish to thank ISDA for their financial and intellectual support.

*Max L. Heine Professor of Finance and Vice Director of the NYU Salomon Center, Stern School of Business, New York, U.S.A.

** Associate Director, Standard \& Poor's Risk Solutions Group. Mr. Brady was a Ph.D. student at Stern when this work was completed.

*** Associate Professor of Finance, Department of Mathematics and Statistics, Bergamo University, Italy.

**** Professor of Financial Markets and Institutions and Director of the Research Division of SDA Business School, Bocconi University, Milan, Italy

The authors wish to thank Richard Herring, Hiroshi Nakaso and the other participants to the BIS conference (March 6, 2002) on "Changes in risk through time: measurement and policy options" for their useful comments. The paper also profited by the comments from participants in the CEMFI (Madrid, Spain) Workshop on April 2, 2002, especially Rafael Repullo, Enrique Sentana, and Jose Campa, and from Workshops at Stern School of Business (NYU), University of Antwerp, University of Verona and Bocconi University. 


\section{Introduction}

Credit risk affects virtually every financial contract. Therefore the measurement, pricing and management of credit risk has received much attention from financial economists, bank supervisors and regulators, and from financial market practitioners. Following the recent attempts of the Basel Committee on Banking Supervision (1999, 2001a) to reform the capital adequacy framework by introducing risk-sensitive capital requirements, significant additional attention has been devoted to the subject of credit risk measurement by the international regulatory, academic and banking communities.

This paper analyzes the impact of various assumptions on which most credit risk measurement models are presently based: namely, it analyses the association between aggregate default probabilities and the loss given default on bank loans and corporate bonds, and seeks to empirically explain this critical relationship. Moreover, it simulates the effects of this relationship on credit $\mathrm{VaR}$ models, as well as on the procyclicality effects of the new capital requirements proposed in 2001 by the Basel Committee. Before we proceed with empirical and simulated results, however, the following section is dedicated to a brief review of the theoretical literature on credit risk modeling of the last three decades.

\section{The Relationship Between Default Rates and Recovery Rates in Credit Risk Modeling: a Review of the Theoretical and Empirical Literature}

Credit risk models can be divided into two main categories: (a) credit pricing models, and (b) portfolio credit value-at-risk (VaR) models. Credit pricing models can in turn be divided into three main approaches: (i) "first generation" structural-form models, (ii) "second generation" structural-form models, and (iii) reduced-form models. These three different approaches, together with their basic assumptions, advantages, drawbacks and empirical performance, are briefly outlined in the following paragraphs. Credit VaR models are then examined. Finally, the more recent studies explicitly modeling and empirically investigating the relationship between the probability of default (PD) and recovery rates (RR) are briefly analyzed.

\subsection{First generation structural-form models: the Merton approach}

The first category of credit risk models are the ones based on the original framework developed by Merton (1974), using the principles of option pricing (Black and Scholes, 1973). In such a framework, the default process of a company is driven by the value of the company's 
assets and the risk of a firm's default is explicitly linked to the variability in the firm's asset value. The basic intuition behind this model is relatively simple: default occurs when the value of a firm's assets (the market value of the firm) is lower than that of its liabilities. The payment to the debtholders at the maturity of the debt is therefore the smaller of two quantities: the face value of the debt or the market value of the firm's assets. Assuming that the company's debt is entirely represented by a zero-coupon bond, if the value of the firm at maturity is greater than the face value of the bond, then the bondholder gets back the face value of the bond. However, if the value of the firm is less than the face value of the bond, the equityholders get nothing and the bondholder gets back the market value of the firm. The payoff at maturity to the bondholder is therefore equivalent to the face value of the bond minus a put option on the value of the firm, with a strike price equal to the face value of the bond and a maturity equal to that of the bond. Following this basic intuition, Merton derived an explicit formula for default risky bonds which can be used both to estimate the PD of a firm and to estimate the yield differential between a risky bond and a default-free bond ${ }^{1}$.

Under these models all the relevant credit risk elements, including default and recovery at default, are a function of the structural characteristics of the firm: asset volatility (business risk) and leverage (financial risk). The RR, although not treated explicitly in these models, is therefore an endogenous variable, as the creditors' payoff is a function of the residual value of the defaulted company's assets. More precisely, under Merton's theoretical framework, PD and RR are inversely related. If, for example, the firm's value increases, then its PD tends to decrease while the expected RR at default increases (ceteris paribus). On the other side, if the firm's debt increases, its PD increases while the expected RR at default decreases. Finally, if the firm's asset volatility increases, its PD increases while the expected RR at default decreases ${ }^{2}$.

\footnotetext{
${ }^{1}$ In addition to Merton (1974), first generation structural-form models include Black and Cox (1976), Geske (1977), and Vasicek (1984). Each of these models tries to refine the original Merton framework by removing one or more of the unrealistic assumptions. Black and Cox (1976) introduce the possibility of more complex capital structures, with subordinated debt; Geske (1977) introduces interest-paying debt; Vasicek (1984) introduces the distinction between short and long term liabilities, which now represents a distinctive feature of the KMV model.

${ }^{2}$ One might point out that in the Merton model, since asset values evolve as a continuous process and a firm defaults as soon as its assets fall below its liabilities, then the firm will be liquidated for almost the value of its debt and the loss rate will be intrinsically negligible (ie. recovery rates will always be close to $100 \%$ ). However, in Merton's framework, debt becomes due at a fixed future date, and by that date the asset value can be much lower than that of liabilities, so high loss rates are also possible. Moreover, the negative link between PD and RR is clear when one thinks of the expected recovery rates for performing firms: a sudden decrease in the assets, a rise in debt, an increase in volatility may leave a firm solvent, yet they will increase its PD and, at the same time, reduce its expected RR. See Altman Resti and Sironi, 2001, for a formal analysis of this relationship.
} 


\subsection{Second generation structural-form models}

Although the line of research that followed the Merton approach has proven very useful in addressing the qualitatively important aspects of pricing credit risks, it has been less successful in practical pricing applications ${ }^{3}$. In response to such difficulties, an alternative approach has been developed which still adopts the original framework as far as the default process is concerned but, at the same time, removes one of the unrealistic assumptions of the Merton model, namely, that default can occur only at maturity of the debt when the firm's assets are no longer sufficient to cover debt obligations. Instead, it is assumed that default may occur at any time between the issuance and maturity of the debt, when the value of the firm's assets reaches a lower threshold level ${ }^{4}$. These models include Kim, Ramaswamy and Sundaresan (1993), Hull and White (1995), Nielsen, Saà-Requejo and Santa Clara (1993), Longstaff and Schwartz (1995) and others.

Under these models, the RR in the event of default is exogenous and independent from the firm's asset value. It is generally defined as a fixed ratio of the outstanding debt value and is therefore independent from the PD. This approach simplifies the first class of models by both exogenously specifying the cash flows to risky debt in the event of bankruptcy and simplifying the bankruptcy process. This occurs when the value of the firm's underlying assets hits some exogenously specified boundary.

Despite these improvements, second generation structural-form models still suffer from three main drawbacks, which represent the main reasons behind their relatively poor empirical performance ${ }^{5}$. First, they still require estimates for the parameters of the firm's asset value, which is nonobservable. Second, they cannot incorporate credit-rating changes that occur quite frequently for default-risky corporate debts. Finally, most structural-form models assume that the value of the firm is continuous in time. As a result, the time of default can be predicted just before it happens and hence, as argued by Duffie and Lando (2000), there are no "sudden surprises".

\footnotetext{
${ }^{3}$ The standard reference is Jones, Mason and Rosenfeld (1984), who find that, even for firms with very simple capital structures, a Merton-type model is unable to price investment-grade corporate bonds better than a naive model that assumes no risk of default.

${ }^{4}$ One of the earliest studies based on this framework is Black and Cox (1976). However, this is not included in the second-generation models in terms of the treatment of the recovery rate.

${ }^{5}$ See Eom, Helwege and Huang (2001) for an empirical analysis of structural-form models.
} 


\subsection{Reduced-form models}

The attempt to overcome the above mentioned shortcomings of structural-form models gave rise to reduced-form models. These include Litterman and Iben (1991), Madan and Unal (1995), Jarrow and Turnbull (1995), Jarrow, Lando and Turnbull (1997), Lando (1998), Duffie and Singleton (1999), and Duffie (1998). Unlike structural-form models, reduced-form models do not condition default on the value of the firm, and parameters related to the firm's value need not be estimated to implement them. In addition, reduced-form models introduce separate, explicit assumptions on the dynamics of both PD and RR. These variables are modeled independently from the structural features of the firm, its asset volatility and leverage. Generally, reduced-form models assume an exogenous RR that is independent from the PD. More specifically, they take as given the behavior of default-free interest rates, the RR of defaultable bonds at default, as well as a stochastic intensity process for default. At each instant there is some probability that a firm defaults on its obligations. Both this probability and the RR in the event of default may vary stochastically through time, although they are not formally linked to each other. The stochastic processes determine the price of credit risk. Although these processes are not formally linked to the firm's asset value, there is presumably some underlying relation, thus Duffie and Singleton (1999) describe these alternative approaches as reduced-form models.

Reduced-form models fundamentally differ from typical structural-form models in the degree of predictability of the default. A typical reduced-form model assumes that an exogenous random variable drives default and that the probability of default over any time interval is nonzero. Default occurs when the random variable undergoes a discrete shift in its level. These models treat defaults as unpredictable Poisson events. The time at which the discrete shift will occur cannot be foretold on the basis of information available today ${ }^{6}$.

Empirical evidence concerning reduced-form models is rather limited. Using the Duffie and Singleton (1999) framework, Duffee (1999) finds that these models have difficulty in explaining the observed term structure of credit spreads across firms of different qualities. In particular, such models have difficulty generating both relatively flat yield spreads when firms have low credit risk and steeper yield spreads when firms have higher credit risk.

\footnotetext{
6 A recent attempt to combine the advantages of structural-form models - a clear economic mechanism behind the default process - and the ones of reduced-form models - unpredictability of default - can be found in Zhou (2001). This is done by modeling the evolution of firm value as a jump-diffusion process. This model links RRs to the firm
} 


\subsection{Credit Value-at-Risk Models}

During the second part of the nineties, both banks and consultants started developing credit risk models aimed at measuring the potential loss, with a predetermined confidence level, that a portfolio of credit exposures could suffer within a specified time horizon (generally one year). These vaue-at-risk (VaR) models include J.P. Morgan's CreditMetrics ${ }^{\circledR}$ (Gupton, Finger and Bhatia [1997]), Credit Risk Financial Products' CreditRisk ${ }^{\circledR}$ (1997), McKinsey’s CreditPortfolioView ${ }^{\circledR}$ (Wilson [1997a, 1997b, 1998]), and KMV’s CreditPortfolioManager® (McQuown, [1993] and Crosbie [1999]). These models can largely be seen as reduced-form models, where the RR is typically taken as an exogenous constant parameter or a stochastic variable independent from PD. Some of these models, such as CreditMetrics®, CreditPortfolioView ${ }^{\circledR}$ and CreditManager ${ }^{\circledR}$, treat the $\mathrm{RR}$ in the event of default as a stochastic variable - generally modeled through a beta distribution - independent from the PD. Others, such as CreditRisk ${ }^{+}$, treat it as a constant parameter that must be specified as an input for each single credit exposure. While a comprehensive analysis of these models goes beyond the aim of this literature review ${ }^{7}$, it is important to highlight that all credit VaR models treat RR and PD as two independent variables.

\subsection{Some recent contributions on the PD-RR relationship}

During the last two years, new approaches explicitly modeling and empirically investigating the relationship between $\mathrm{PD}$ and RR have been developed. These models include Frye (2000a and 2000b), Jokivuolle and Peura (2000), Jarrow (2001), and Carey and Gordy (2001). Section 3 of this paper provides, we believe, the clearest evidence of a strong negative correlation between PD and RR, at the macro level.

The model proposed by Frye (2000a and 2000b) draws from the conditional approach suggested by Finger (1999) and Gordy (2000b). In these models, defaults are driven by a single systematic factor - the state of the economy - rather than by a multitude of correlation parameters. These models are based on the assumption that the same economic conditions that cause default to rise might cause RRs to decline, i.e. that the distribution of recovery is different

value at default so that the variation in RRs is endogenously generated and the correlation between RRs and credit ratings before default, reported in Altman (1989) and Gupton, Gates and Carty (2000), is justified.

7 For a comprehensive analysis of these models, see Crouhy, Galai and Mark (2000), Gordy (2000a) Saunders (1999) and Saunders and Allen (2002). 
in high-default time periods from low-default ones. In Frye's model, both PD and RR depend on the state of the systematic factor. The correlation between these two variables therefore derives from their mutual dependence on the systematic factor.

The intuition behind Frye's theoretical model is relatively simple: if a borrower defaults on a loan, a bank's recovery may depend on the value of the loan collateral. The value of the collateral, like the value of other assets, depends on economic conditions. If the economy experiences a recession, RRs may decrease just as default rates tend to increase. This gives rise to a negative correlation between default rates and RRs.

While the model originally developed by Frye (2000a) implied recovery from an equation that determines collateral, Frye (2000b) modeled recovery directly. This allowed him to empirically test his model using data on defaults and recoveries from the U.S. corporate bond market. More precisely, data from Moody's Default Risk Service database for the 1982-1997 period have been used for the empirical analysis. Results show a strong negative correlation between default rates and RRs for corporate bonds. This evidence is consistent with the most recent U.S. bond market data, indicating a simultaneous increase in default rates and LGDs for both 1999 and $2000^{8}$. Frye's (2000b and 2000c) empirical analysis allows him to conclude that in a severe economic downturn, bond recoveries might decline 20-25 percentage points from their normal-year average. Loan recoveries may decline by a similar amount, but from a higher level.

Jarrow (2001) presents a new methodology for estimating RRs and PDs implicit in both debt and equity prices. As in Frye (2000a and 2000b), RRs and PDs are correlated and depend on the state of the macroeconomy. However, Jarrow's methodology explicitly incorporates equity prices in the estimation procedure, allowing the separate identification of RRs and PDs and the use of an expanded and relevant dataset. In addition, the methodology explicitly incorporates a liquidity premium in the estimation procedure, which is considered essential in light of the high variability in the yield spreads between risky debt and U.S. Treasury securities.

Using four different datasets, Carey and Gordy (2001) analyze LGD measures and their correlation with default rates. Their preliminary results contrast with the findings of Frye (2000b): estimates of simple default rate-LGD correlation are close to zero. They also find that

\footnotetext{
${ }^{8}$ Hamilton, Gupton and Berthault (2001) and Altman and Brady (2002) provide clear empirical evidence of this phenomenon.
} 
limiting the sample period to 1988-1998, estimated correlations are more in line with Frye's results $(0.45$ for senior debt and 0.8 for subordinated debt). The authors note that, during this short period, the correlation rises, not so much because LGDs are low during the low-default years 1993-1996, but rather because LGDs are relatively high during the high-default years 1990 and 1991. They therefore conclude that the basic intuition behind the Frye's model may not adequately characterize the relationship between default rates and LGDs. Indeed, a weak or asymmetric relationship suggests that default rates and LGDs may be influenced by different components of the economic cycle ${ }^{9}$.

A rather different approach is the one proposed by Jokivuolle and Peura (2000). The authors present a model for bank loans in which collateral value is correlated with the $\mathrm{PD}$. They use the option pricing framework for modeling risky debt: the borrowing firm's total asset value determines the event of default. However, the firm's asset value does not determine the RR. Rather, the collateral value is in turn assumed to be the only stochastic element determining recovery. Because of this assumption, the model can be implemented using an exogenous PD, so that the firm asset value parameters need not be estimated. In this respect, the model combines features of both structural-form and reduced-form models. A counterintuitive result of the Jokivuolle and Peura theoretical model is that the expected RR increases as PD increases. This result is obtained assuming a positive correlation between firm's asset value and collateral value under a structural-form type of framework. A low PD therefore implies that the firm's asset value has to strongly decline in the future before default can occur. Therefore, a positive correlation between asset value and collateral value implies that the latter is likely to be relatively low, too, in the case of default. For high PDs the firm asset value does not have to decline equally substantially before default can occur. Hence, the collateral value in default is on average also higher relative to its original value than in the case of low PD.

Using Moody's historical bond market data, $\mathrm{Hu}$ and Perraudin (2002) examine the dependence between recovery rates and default rates. They first standardize the quarterly recovery data in order to filter out the volatility of recovery rates given by the variation over time in the pool of borrowers rated by Moody's. They find that typical correlations between quarterly

\footnotetext{
${ }^{9}$ Using defaulted bonds' data for the sample period 1982-2000, which include the relatively high default period of 1999 and 2000, we show empirical results that appear consistent with Frye's intuition: a negative correlation between default rates and RRs. However, we find that the single systematic risk factor - i.e. the performance of the economy - is less predictive than Frye's model would suggest. We devote section 3 of this paper to the empirical analysis.
} 
recovery rates and default rates for bonds issued by US-domiciled obligors are $-22 \%$ for post 1982 data (1983-2000) and $-19 \%$ for the 1971-2000 period. Using extreme value theory and other non-parametric techniques, they also examine the impact of this negative correlation on credit $\mathrm{VaR}$ measures and find that the increase is statistically significant when confidence levels exceed $99 \%$.

\subsection{Concluding remarks}

Table 1 summarizes the way RR and its relationship with PD are dealt with in the different credit models described in this literature review. While in the original Merton (1974) framework an inverse relationship between PD and RR exists, the credit risk models developed during the nineties treat these two variables as independent. This assumption strongly contrasts with the growing empirical evidence showing a negative correlation between default and recovery rates (Frye [2000b and 2000c], Altman [2001], Carey and Gordy [2001], and Hamilton, Gupton and Berthault [2001]). This evidence indicates that recovery risk is a systematic risk component. As such, it should attract risk premia and should adequately be considered in credit risk management applications. In the next section we relax the assumption of independence between PD and RR and simulate the impact on VaR models when these two variables are negatively correlated. 
Table 1 - The Treatment of LGD and Default Rates within Different Credit Risk Models

\begin{tabular}{|c|c|c|c|}
\hline & MAIN MODELS \& RELATED EMPIRICAL STUDIES & TREATMENT OF LGD & RELATIONSHIP BETWEEN RR AND PD \\
\hline \multicolumn{4}{|c|}{ Credit Pricing Models } \\
\hline $\begin{array}{l}\text { Second generation } \\
\text { structural-form } \\
\text { models }\end{array}$ & $\begin{array}{l}\text { Kim, Ramaswamy e Sundaresan (1993), } \\
\text { Nielsen, Saà-Requejo, Santa Clara (1993), Hull } \\
\text { and White (1995), Longstaff and Schwartz } \\
\text { (1995). }\end{array}$ & $\begin{array}{l}\text { RR is exogenous and } \\
\text { independent from the firm's } \\
\text { asset value. }\end{array}$ & $\begin{array}{l}\mathrm{RR} \text { is generally defined as a fixed } \\
\text { ratio of the outstanding debt value } \\
\text { and is therefore independent from PD. }\end{array}$ \\
\hline Reduced-form models & $\begin{array}{l}\text { Litterman and Iben (1991), Madan and Unal } \\
\text { (1995), Jarrow and Turnbull (1995), Jarrow, } \\
\text { Lando and Turnbull (1997), Lando (1998), } \\
\text { Duffie and Singleton (1999), Duffie (1998) and } \\
\text { Duffee (1999). }\end{array}$ & $\begin{array}{l}\text { Reduced-form models assume } \\
\text { an exogenous RR that is either a } \\
\text { constant or a stochastic variable } \\
\text { independent from PD. }\end{array}$ & $\begin{array}{l}\text { Reduced-form models introduce } \\
\text { separate assumptions on the dynamic } \\
\text { of PD and RR, which are modeled } \\
\text { independently from the structural } \\
\text { features of the firm. }\end{array}$ \\
\hline $\begin{array}{l}\text { Latest contributions } \\
\text { on the PD-RR } \\
\text { relationship }\end{array}$ & $\begin{array}{l}\text { Frye (2000a and 2000b), Jarrow (2001), Carey } \\
\text { and Gordy (2001), Hu and Perraudin (2002), } \\
\text { Altman and Brady (2002). }\end{array}$ & $\begin{array}{l}\text { Both PD and RR are stochastic } \\
\text { variables which depend on a } \\
\text { common systematic risk factor } \\
\text { (the state of the economy). }\end{array}$ & $\begin{array}{l}\text { PD and RR are negatively correlated. } \\
\text { In the "macroeconomic approach" } \\
\text { this derives from the common } \\
\text { dependence on one single systematic } \\
\text { factor. In the "microeconomic } \\
\text { approach" it derives from the supply } \\
\text { and demand of defaulted securities. }\end{array}$ \\
\hline \multicolumn{4}{|c|}{ Credit Value at Risk Models } \\
\hline CreditMetrics ${ }^{\circledR}$ & Gupton, Finger and Bhatia (1997). & Stochastic variable (beta distr.) & RR independent from PD \\
\hline CreditPortfolioView ${ }^{\circledR}$ & Wilson (1997a and 1997b). & Stochastic variable & RR independent from PD \\
\hline CreditRisk $+\circledR$ & Credit Suisse Financial Products (1997). & Constant & RR independent from PD \\
\hline KMV CreditManager ${ }^{\circledR}$ & McQuown (1997), Crosbie (1999). & Stochastic variable & RR independent from PD \\
\hline
\end{tabular}




\section{The Effects of the Probability of Default-Loss Given Default Correlation on Credit Risk}

\section{Measures: Simulation Results}

This section of the paper is dedicated to an analysis of the effects that the correlation between default and recovery risk would imply for the risk measures derived from the most common credit VaR models. For example, as discussed earlier, the basic version of the Creditrisk+ ${ }^{\circledR}$ model treats recovery as a deterministic component; in other words, a credit exposure of 100 dollars with an estimated recovery rate after default of $30 \%$ is dealt with the same as an exposure of 70 dollars with a fixed loss given default (LGD) of $100 \%$. The Creditmetrics ${ }^{\circledR}$ model allows for individual LGDs to be stochastic (the actual recovery rate on a defaulted loan is drawn from a beta distribution, through a Montecarlo simulation); however, the recovery rate is drawn independently of default probabilities, and an increase in default risk leaves the distribution of recovery rates unchanged.

To test the effects of such assumptions, we run Montecarlo experiments on a sample portfolio and compare the risk measures obtained under three different approaches. Recovery rates will be alternatively treated as:

a. deterministic (like in the Creditrisk+ approach);

b. stochastic, yet uncorrelated with the probabilities of default (PDs - like in the Creditmetrics framework);

c. stochastic, and partially correlated with default risk (as might happen in real life).

By doing so, we are able to assess whether the computations of risk are different among the three approaches. In other words, if we eventually find that default and recovery rates are significantly and negatively correlated, as we suspect, then our simulations would show by how much the first and second approaches underestimate risk, compared to the third one. The results obtained depend on the actual portfolio considered in the simulation. However, since we use a large portfolio (with a high number of assets of different credit quality), we believe that the final outcome is general enough to apply to a wide array of real-life situations.

\subsection{Experimental setup}

Figure 1 presents the benchmark portfolio used in our experiment. It includes 250 loans, generating a total exposure of 7.5 million Euros belonging to seven different rating grades. 
Individual exposures are shown on the $\mathrm{x}$-axis, while the $\mathrm{y}$-axis reports the PD levels associated with the rating classes ${ }^{10}$ (ranging from $0.5 \%$ to $5 \%$ ). As can be seen, the array of borrowers included in the benchmark portfolio looks widely diversified, as regards both credit quality and size; it should therefore be general enough to represent real-life loan portfolios.

Figure 2 summarizes our simulation procedure. Our simulation engine draws heavily on the Creditrisk+ approach, as described in Credit Suisse Financial Products (1997). Note, however, that we are not going to follow the Creditrisk+ model as far as the computation of expected losses and risk measures is concerned, but will keep the simulation framework as flexible as possible to accommodate the three different treatments of recovery risk outlined in the section's overview.

As in all Montecarlo experiments, a large number of scenarios $(100,000)$ is drawn from a simulation engine, and the empirical distribution of such scenarios is then used as a proxy for the theoretical distribution of losses (computing its expected value, standard deviation and some percentile-based risk measures).

Every scenario is based on the following logic: in the short run, the default probability of each obligor can be seen as the product of two components: the long-term PD of the borrower (i.e., the value reported on the $y$-axis in Figure 1) and a short-term shock, due both to macroeconomic and individual factors. Individual characteristics may be based, for example, on the obligor's industry, its size and the age of the loan/bond facility. In symbols:

$$
P D_{\text {short }}=P D_{\text {long }} \cdot \text { Shock }
$$

This approach accounts for the fact that firms with different ratings tend to have, on average, different default rates, and that, nevertheless, their actual PDs might fluctuate over time according to the state of the economy and the firms' cash flow and profit cycles. In a sense, we are combining "through the cycle" default estimates expounded by the rating agencies with "point in time" adjustments implied in short term estimates of the type found in Basel 2's and credit value-at-risk models.

\footnotetext{
${ }^{10}$ Note that these are long-term PDs that are going to be revised upwards or downwards in the short term because of both macroeconomic and idiosyncratic factors (see below).
} 


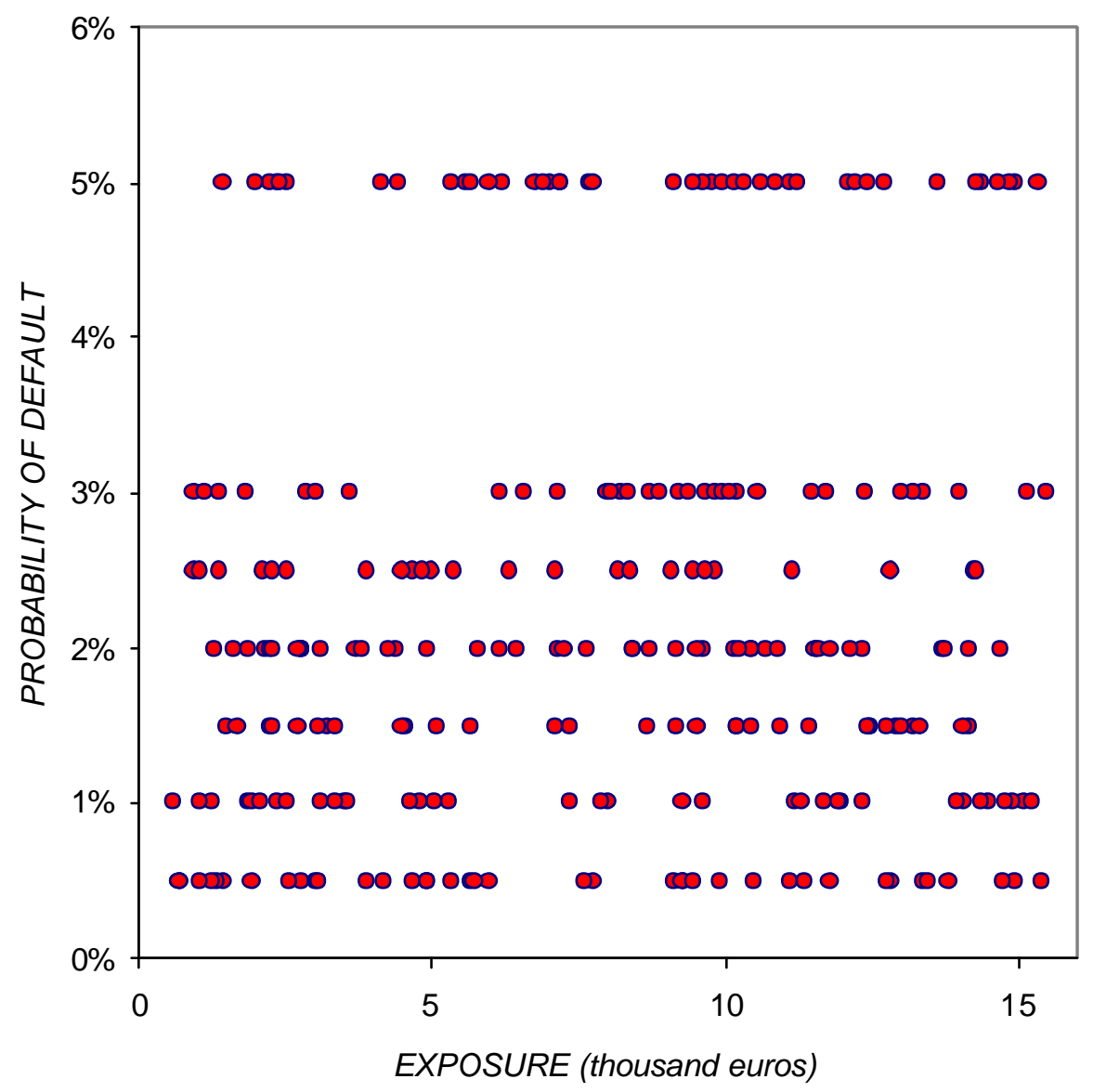

Figure 1: PD and exposure of the 250 loans included in the benchmark portfolio 


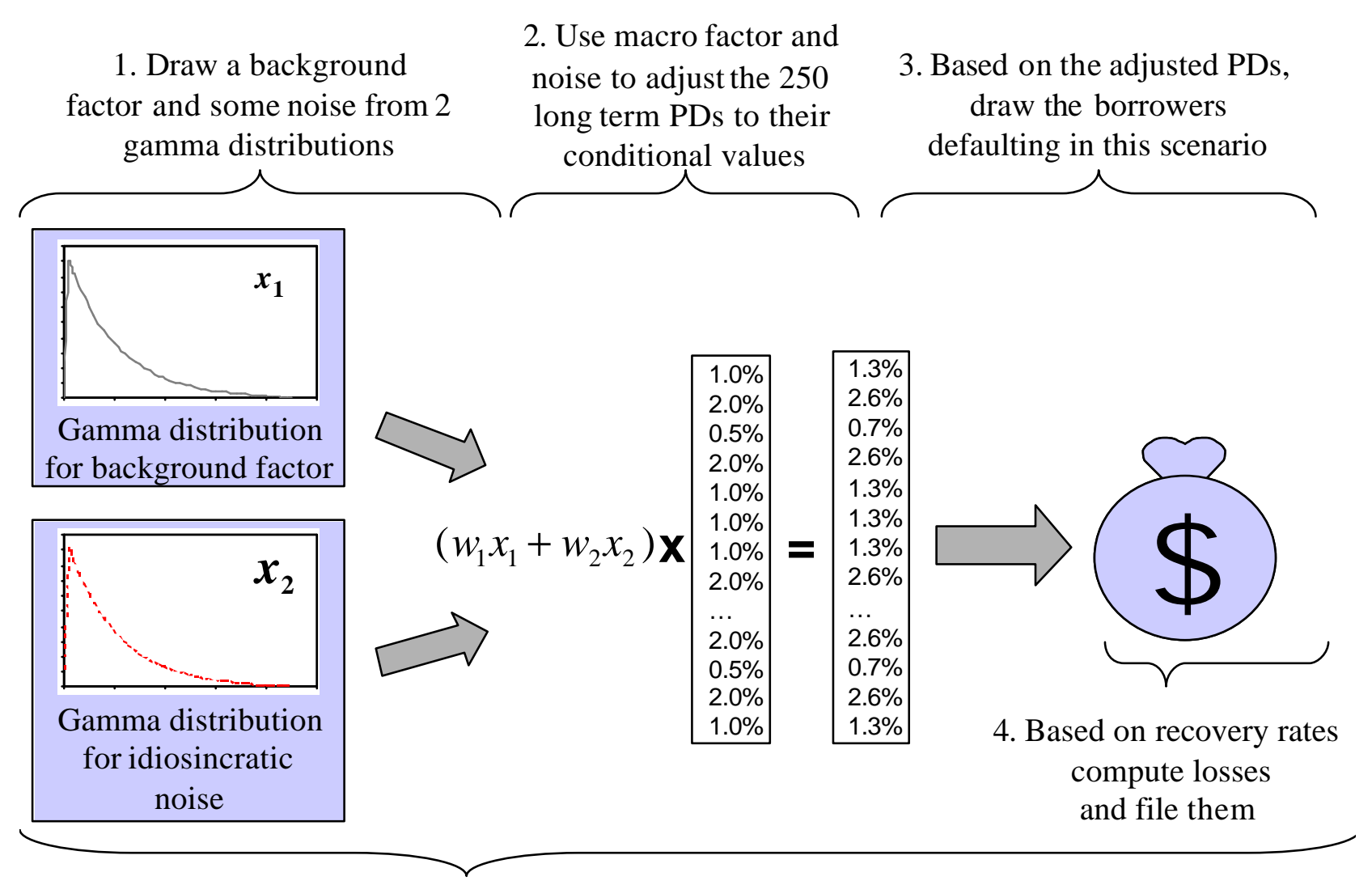

5. Loop 100,000 times

Figure 2: the simulation engine used in our experiment

More specifically, the short-term shock can be thought of as the weighted sum of two random components, both drawn from independent gamma distributions with mean equal to one ${ }^{11}: x_{1}$ represents a background factor that is common to all the borrowers in the portfolio (the risk of an economic downturn affecting all bank customers), while $x_{2}$ is different for every obligor, and represents idiosyncratic risk:

$$
\text { Shock }=w_{1} x_{1}+w_{2} x_{2}
$$

Note that, according to this framework, a recession would bring about a very high value for $x_{1}$ which, after being combined with the individual components (the $x_{2} \mathrm{~s}$ ), would significantly increase the short term PDs of most borrowers, bringing them above their average long-term values. This would make the bank's portfolio more vulnerable to default risk, since the actual number of defaults experienced over the following year would be higher. Indeed, if we were

\footnotetext{
${ }^{11}$ In this way, the expected short-term PD will be the long-term value associated with each rating class.
} 
simulating all rating changes, the number of downgrades vs. no change or upgrades would increase as well. This is related to the "procyclicality" effect that may be an important issue inherent in any rating-based capital requirement standards.

The weights $w_{1}$ and $w_{2}$, through which the macroeconomic and individual shocks are combined, must be set carefully, since they play an important role in the final results. If too much emphasis is attributed to systemic risk $x_{1}$, then the short-term PDs of all borrowers would mechanically respond to the macroeconomic cycle, and defaults would take place in thick clusters (increasing the variance of bank losses, i.e., the risk that must be faced by bank shareholders and regulators). Conversely, if a significant weight is given to the idiosyncratic risk $x_{2}$, then the defaults by different borrowers would be entirely uncorrelated and the stream of bank losses over time could appear quite smooth (since individual risks could be diversified away).

In order to keep things as simple and transparent as possible, we use a simple fifty-fifty weighting scheme in our simulation. Note that - although it represents an arbitrary choice - this is not dramatically different from the 33\%-66\% scheme underlying the new regulatory framework proposed by the Basel committee in its January 2001 document $^{12}$.

We now return to Figure 2, to see how this logic was implemented in our simulation. For each scenario:

1. A value for the background factor $x_{1}$ is drawn from a gamma distribution ${ }^{13}$; this value, which is common to all borrowers in the portfolio, is combined with an idiosyncratic noise term ( $x_{2}$, also taken from a gamma), which is different for every obligor.

2. The combination of $x_{1}$ and $x_{2}$ is used to shock the long-term values of the obligors' PDs in order to obtain the short-term probabilities that will be used in the following steps. Note that when $x_{1}$ is low, most PDs will be revised downwards (as it happens when a

\footnotetext{
12 In the January 2001 Basel document, default occurs because of changes in a firm's asset value; these, in turn, follow a standard normal distribution which combines a macro factor (with a weight of about .45) and an idiosyncratic term (with a weight of .89); hence the 33\%-66\% proportion quoted in the text. However, as noted by many observers who discussed the Basel proposals, the idiosyncratic component should probably be given more importance for small borrowers, while the systematic component should be more relevant for large firms, the credit quality of which tends to depend more heavily on the overall economic cycle. This remark sounds quite correct, yet using different weights for each borrower, depending on her size, would have made our simulation longer and less transparent. Therefore, we decided to stick to the simplest rule, the "fifty-fifty" weighting.

${ }^{13}$ We use gamma distributions because they are highly skewed to the right, accounting for the fact that default probabilities tend to stay low most of the time, but can increase dramatically in some (rare) extreme scenarios.
} 
healthy economy makes default risk smaller for most borrowers); on the other hand, when $x_{1}$ is high, default probabilities will be adjusted according to a more risky economic environment (see again Figure 2).

3. Based on the adjusted PDs, the computer draws which borrowers will actually default in this scenario. A loan with a $10 \% \mathrm{PD}$ is more likely to default than one with a $2 \%$ PD. However, due to the random error, the latter might go bust while the former survives. This step of the simulation provides us with a list of defaulted borrowers.

4. For each defaulted loan in the list, the amount of losses is computed. This step can be performed in three different ways, depending on the assumptions concerning LGD. More details will be given in the following paragraph.

5. The loss amount generated by this scenario is filed, and a new scenario is started.

\subsection{The computation of $L G D$ s}

The Montecarlo simulation described above was repeated three times, changing the way in which LGDs were handled. We tested the three different approaches highlighted at the beginning of this section:

a) First, LGD is deterministic. In this case we simply multiply the exposure of each defaulted asset by an "average" loss given default. To keep things simple, we use a $30 \%$ LGD for all borrowers, which is also the mean of the beta distribution utilized in approach (b).

b) Secondly, LGD is stochastic but uncorrelated with default probabilities. In this case, LGD is separately drawn for each borrower from a beta distribution limited between $10 \%$ and $50 \%$, with mean $30 \%$ and with a variance such that $5 / 9$ of all values are bound between $20 \%$ and $40 \%$.

c) Finally, LGD is stochastic and correlated with default probabilities. In this case, we are still using the same beta distribution as above, but we impose a perfect rank correlation between the LGD and the background factor $x_{1}{ }^{14}$. For example, when the background factor $x_{1}$ takes a very high value (thereby signalling that the economy is facing a

\footnotetext{
${ }^{14}$ In other words, for every possible value $x_{1} *$ of the background factor $x_{1}$, such that $p\left(x_{1}<x_{1} *\right)=P$, we choose the LGD as the $P$ th percentile of its (beta) distribution.
} 
recession), the LGDs increase up to 50\%; on the other hand, when the economy improves, LGDs can become as low as $10 \%$.

\subsection{Main Results}

Table 2 shows the main outcomes of our simulation exercise. The first three columns of data show loss and risk indicators obtained under the three approaches discussed in the previous paragraph. The last column quantifies the increase in those indicators when we move from the "quiet" world, where no recovery risk is present, to the more "dangerous" one where default and recovery risk tend to move together. All $\mathrm{VaR}$ measures (regardless of the confidence interval chosen), as well as the standard deviation, look considerably underestimated when recovery risk is overlooked.

We find that not only unexpected losses (i.e. the standard error and percentiles), but also expected losses tend to increase materially when shifting from column "a" to "c". This looks especially important since expected losses are generally thought to be computed correctly by multiplying the (long term) PD by the expected LGD. The numbers in Table 2 suggest that such a straightforward practice might not be correct and seriously understate the actual loss ${ }^{15}$.

Table 2

\section{Main results of the LGD simulation}

\begin{tabular}{lcccc}
\hline \multicolumn{5}{c}{ LGD modelled according to approach } \\
& $(a)$ & $(b)$ & $(c)$ & \% error \\
& 463 & 458 & 598 & $29.4 \%$ \\
\hline Expected Loss & 982 & 978 & 1,272 & $29.5 \%$ \\
$95 \%$ VaR & 1,899 & 1,880 & 2,449 & $28.9 \%$ \\
$99 \%$ VaR & 3,835 & 3,851 & 4,972 & $29.6 \%$ \\
$99.5 \%$ VaR & 3,591 & 3,579 & 4,653 & $29.6 \%$ \\
$99.9 \%$ VaR & 3,738 & 3,774 & 4,887 & $30.7 \%$ \\
\hline
\end{tabular}

\footnotetext{
15 This intuition has been scrutinized more carefully and further analysed by means of a simple numeric example in the ISDA report by Altman et al. (2001).
} 
Another noteworthy result is that no significant differences arise when we move from column (a) to (b): in other words, when recovery rates are considered stochastic, but independent on each other, the law of large numbers ensures that all uncorrelated risks can be effectively disposed of. A portfolio of 250 loans already looks large enough to exploit this diversification effect, since its risk measures are not significantly different from the deterministic case. In other words, it is not uncertainty in recovery rates, but positive correlation, that brings about an increase in credit risk. Among all possible kinds of correlation, the link between recovery and default looks to be the most significant and, possibly, dangerous one, since it increases both unexpected and expected losses. Moreover, the percent error found when moving from (a), or (b), to (c) is approximately the same (about 30\%) for all risk and loss measures (expected and unexpected losses, percentile-based indices).

Summing up, if $P D$ and $L G D$ were driven by some common causes, then not only the risk measures based on standard errors and percentiles (i.e., the unexpected losses usually covered with bank capital), but even the amount of "normal" losses to be expected on a given loan (and to be shielded through charge-offs and reserves) could be seriously underestimated by most credit risk models. This reinforces the theoretical relevance of the empirical tests presented in the following Section.

\section{Explaining Aggregate Recovery Rates on Corporate Bond Defaults: Empirical Results}

The average loss experience on credit assets is well documented in studies by the various rating agencies (Moody's, S\&P, and Fitch) as well as by academics ${ }^{16}$. Recovery rates have been released for bonds, stratified by seniority, as well as for bank loans. The latter asset class can be further stratified by capital structure and collateral type. While quite informative, these studies say nothing about the recovery vs. default correlation. The purpose of this section is to empirically test this relationship with actual default data from the U.S. corporate bond market over the last two decades. As Frye (2000a), Altman (2001), Carey and Gordy (2001) and others point out (see Section 1), there is strong intuition suggesting that default and recovery rates

\footnotetext{
${ }^{16}$ See e.g. Altman and Kishore (1996), Altman and Arman (2002), FITCH (1997, 2001), Moody's (2000), Standard $\&$ Poor's (2000).
} 
might be correlated. Accordingly, this third Section of our study attempts to explain the link between the two variables, by specifying rather straightforward statistical models ${ }^{17}$.

We measure aggregate annual bond recovery rates (henceforth: BRR) by the weighted average recovery of all corporate bond defaults, primarily in the United States, over the periods 1982-2000 and also for the shorter period, 1987-2000. The weights are based on the market value of defaulting debt issues of publicly traded corporate bonds ${ }^{18}$. The logarithm of BRR (BLRR) is also analysed. Data from prior to 1982 was too sparse in many years, e.g., less than five defaults in most years, to be meaningful.

The sample includes annual averages from about 1000 defaulted bonds for which we were able to get reliable quotes on the price of these securities just after default. We utilize the database constructed and maintained by the NYU Salomon Center, under the direction of one of the authors. Our models are both univariate and multivariate, least squares regressions. The former can explain up to $60 \%$ of the variation of average annual recovery rates, while the latter explain as much as $90 \%$.

The rest of this Section will proceed as follows. We begin our analysis by describing the independent variables used to explain the annual variation in recovery rates. These include supply-side aggregate variables that are specific to the market for corporate bonds, as well as macroeconomic factors (some demand side factors are also discussed). Next, we describe the results of the univariate analysis. We then describe our multivariate models.

\subsection{Explanatory Variables}

\footnotetext{
${ }^{17}$ We will concentrate on average annual recovery rates but not on the factors that contribute to understanding and explaining recovery rates on individual firm and issue defaults. Van de Castle and Keisman (1999) indicate that factors like capital structure, as well as collateral and seniority, are important determinants of recovery rates and Madan and Unal (2001) propose a model for estimating risk-neutral expected recovery rate distributions - - not empirically observable rates. The latter can be particularly useful in determining prices on credit derivative instruments, such as credit default swaps.

${ }^{18}$ Prices of defaulted bonds are based on the closing levels on or as close to the default date as possible. Precise-date pricing was only possible in the last ten years, or so, since market maker quotes were not available from the NYU Salomon Center database prior to 1990 and all prior date prices were acquired from secondary sources, primarily the S\&P Bond Guides. Those latter prices were based on end-of-month closing bid prices only. We feel that more exact pricing is a virtue since we are trying to capture supply and demand dynamics which may impact prices negatively if some bondholders decide to sell their defaulted securities as fast as possible. In reality, we do not believe this is an important factor since many investors will have sold their holdings prior to default or are more deliberate in their "dumping" of defaulting issues.
} 
We proceed by listing several variables we reasoned could be correlated with aggregate recovery rates. The expected effects of these variables on recovery rates will be indicated by a +/- sign in parentheses. The exact definitions of the variables we use are:

$\boldsymbol{B D R}$ (-) The weighted average default rate on bonds in the high yield bond market and its logarithm (BLDR, -). Weights are based on the face value of all high yield bonds outstanding each year ${ }^{19}$.

$\boldsymbol{B D R C}(-)$ One Year Change in $\boldsymbol{B D R}$.

$\boldsymbol{B O A}$ (-) This is the total amount of high yield bonds outstanding for a particular year (measured at mid-year in trillions of dollars) and represents the potential supply of defaulted securities. Since the size of the high yield market has grown in most years over the sample period, the $\boldsymbol{B O A}$ variable is picking up a time-series trend as well as representing a potential supply factor.

$\boldsymbol{B D A}(-)$ We also examined the more directly related bond defaulted amount as an alternative for $\boldsymbol{B O A}$ (also measured in trillions of dollars).

BIR (+) This is the one-year return on the Altman-NYU Salomon Center Index of Defaulted Bonds, a monthly indicator of the market weighted average performance of a sample of defaulted publicly traded bonds ${ }^{20}$. This is a measure of the price changes of existing defaulted issues as well as the "entry value" of new defaults and, as such, is impacted by supply and demand conditions in this "niche" market. ${ }^{21}$

$\boldsymbol{G D P}(+)$ The annual GDP growth rate.

GDPC (+) The change in the annual GDP growth rate from the previous year.

\footnotetext{
${ }^{19}$ We did not include a variable that measures the distressed, but not defaulted, proportion of the high yield market since we do not know of a time series measure that goes back to 1987 . We define distressed issues as yielding more than 1000 basis points over the risk-free 10-year Treasury Bond Rate. We did utilize the average yield spread in the market and found it was highly correlated (0.67) to the subsequent one year's default rate and hence did not add value (see discussion below). The high yield bond yield spread, however, can be quite helpful in forecasting the following year's BDR, a critical variable in our model.

${ }^{20}$ More details can be found in Altman (1991) and Altman and Pompeii (2002). Note that we use two different time frames in our analyses, 1982-2000 and 1987-2000, because the defaulted bond index return (BIR) has only been calculated since 1987. We go no earlier than 1982 because there are so few default observations before that year.

${ }^{21} \mathrm{We}$ are aware of the fact that the average recovery rate on newly defaulted bond issues could influence the level of the defaulted bond index and vice-versa. The vast majority of issues in the index, however, are usually comprised of bonds that have defaulted in prior periods. And, as we will see, while this variable is significant on an univariate basis and does improve the overall explanatory power of the model, it is not an important contributor. We could only introduce this variable in the 1987-2000 regression.
} 
GDPI (-) Takes the value of 1 when GDP growth was less than $1.5 \%$ and 0 when GDP growth was greater than $1.5 \%$.

$S R(+)$ The annual return on the S\&P 500 stock index.

$S R C(+)$ The change in the annual return on the S\&P 500 stock index from the previous year.

\subsection{The Basic Explanatory Variable: Default Rates}

It is clear that the supply of defaulted bonds is most vividly depicted by the aggregate amount of defaults and the rate of default. Since virtually all public defaults most immediately migrate to default from the non-investment grade or "junk" bond segment of the market, we use that market as our population base. The default rate is the par value of defaulting bonds divided by the total amount outstanding, measured at face values. Table 3 shows default rate data from 1978-2001 as well as the weighted average annual recovery rates (our dependent variable) and the default loss rate (last column). Note that the average annual recovery is $41 \%$ and the weighted average annual loss rate to investors is $3.16 \%{ }^{22}$.

\footnotetext{
${ }^{22}$ The loss rate is impacted by the lost coupon at default as well as the more important lost principal. Default and Recovery rate data does not include Texaco's very large default in 1987 since it was caused by a legal suit and a strategy to avoid paying a huge fine for merger tampering. Hence, it was an outlier default with a very high recovery. If we had included Texaco, our empirical results would be somewhat less significant, with our multivariate $\mathrm{R}^{2}$ still at a robust 0.77 (see results in section 3.5.
} 
Table 3

DEFAULT RATES AND LOSSES

(1978 - 2001)

\begin{tabular}{|c|c|c|c|c|c|}
\hline YEAR & $\begin{array}{c}\text { PAR VALUE } \\
\text { OUTSTANDING (a) } \\
\text { (\$ MMs) }\end{array}$ & $\begin{array}{l}\text { PAR VALUE } \\
\text { OF DEFAULT } \\
\text { (\$ MMs) }\end{array}$ & $\begin{array}{l}\text { DEFAULT } \\
\text { RATE }(\%)\end{array}$ & $\begin{array}{l}\text { WEIGHTED PRICE } \\
\text { AFTER DEFAULT }\end{array}$ & $\begin{array}{r}\text { WEIGHTED } \\
\text { COUPON (\%) }\end{array}$ \\
\hline 2001 & $\$ 649,000$ & $\$ 63,609$ & $9.80 \%$ & $\$ 25.5$ & $9.18 \%$ \\
\hline 2000 & $\$ 597,200$ & $\$ 30,295$ & $5.07 \%$ & $\$ 26.4$ & $8.54 \%$ \\
\hline 1999 & $\$ 567,400$ & $\$ 23,532$ & $4.15 \%$ & $\$ 27.9$ & $10.55 \%$ \\
\hline 1998 & $\$ 465,500$ & $\$ 7,464$ & $1.60 \%$ & $\$ 35.9$ & $9.46 \%$ \\
\hline 1997 & $\$ 335,400$ & $\$ 4,200$ & $1.25 \%$ & $\$ 54.2$ & $11.87 \%$ \\
\hline 1996 & $\$ 271,000$ & $\$ 3,336$ & $1.23 \%$ & $\$ 51.9$ & $8.92 \%$ \\
\hline 1995 & $\$ 240,000$ & $\$ 4,551$ & $1.90 \%$ & $\$ 40.6$ & $11.83 \%$ \\
\hline 1994 & $\$ 235,000$ & $\$ 3,418$ & $1.45 \%$ & $\$ 39.4$ & $10.25 \%$ \\
\hline 1993 & $\$ 206,907$ & $\$ 2,287$ & $1.11 \%$ & $\$ 56.6$ & $12.98 \%$ \\
\hline 1992 & $\$ 163,000$ & $\$ 5,545$ & $3.40 \%$ & $\$ 50.1$ & $12.32 \%$ \\
\hline 1991 & $\$ 183,600$ & $\$ 18,862$ & $10.27 \%$ & $\$ 36.0$ & $11.59 \%$ \\
\hline 1990 & $\$ 181,000$ & $\$ 18,354$ & $10.14 \%$ & $\$ 23.4$ & $12.94 \%$ \\
\hline 1989 & $\$ 189,258$ & $\$ 8,110$ & $4.29 \%$ & $\$ 38.3$ & $13.40 \%$ \\
\hline 1988 & $\$ 148,187$ & $\$ 3,944$ & $2.66 \%$ & $\$ 43.6$ & $11.91 \%$ \\
\hline $1987 b$ & $\$ 129,557$ & $\$ 1,736$ & $1.34 \%$ & $\$ 62.0$ & $12.07 \%$ \\
\hline 1986 & $\$ 90,243$ & $\$ 3,156$ & $3.50 \%$ & $\$ 34.5$ & $10.61 \%$ \\
\hline 1985 & $\$ 58,088$ & $\$ 992$ & $1.71 \%$ & $\$ 45.9$ & $13.69 \%$ \\
\hline 1984 & $\$ 40,939$ & $\$ 344$ & $0.84 \%$ & $\$ 48.6$ & $12.23 \%$ \\
\hline 1983 & $\$ 27,492$ & $\$ 301$ & $1.09 \%$ & $\$ 55.7$ & $10.11 \%$ \\
\hline 1982 & $\$ 18,109$ & $\$ 577$ & $3.19 \%$ & $\$ 38.6$ & $9.61 \%$ \\
\hline
\end{tabular}

ARITHMETIC AVERAGE 1982-2001:

$3.50 \%$

$\$ 44.1$

$11.13 \%$

Notes

(a) Excludes defaulted issues.

Source: Authors' Compilations and various dealer price quotes.

(b) Does not include Texaco's bankruptcy. 


\subsection{The Demand and Supply of Distressed Securities}

The principal purchasers of defaulted securities, primarily bonds and bank loans, are niche investors called distressed asset or alternative investment managers - also called "vultures." Prior to 1990, there was little or no analytic interest in these investors, indeed in he distressed debt market, except for the occasional anecdotal evidence of performance in such securities. Altman (1991) was the first to attempt an analysis of the size and performance of the distressed debt market and estimated, based on a fairly inclusive survey, that the amount of funds under management by these so-called vultures was at least $\$ 7.0$ billion in 1990 and if you include those investors who did not respond to the survey and non-dedicated investors, the total was probably in the $\$ 10-12$ billion range. Cambridge Associates (2001) estimated that the amount of distressed assets under management in 1991 was \$6.3 billion. Estimates since 1990 indicate that the demand did not rise materially until 2000-2001, when our latest estimate is a total demand for distressed securities of \$40-45 billion as of December 31, 2001 (see Altman and Pompeii, 2002).

On the supply side, the last decade has seen the amounts of distressed and defaulted public and private bonds and bank loans grow dramatically in 1990-1991 to as much as \$300 billion (face value) and $\$ 200$ billion (market value), then recede to much lower levels in the 1993-1998 period and grow enormously again in 2000-2001 to the unprecedented levels of $\$ 650$ billion (face value) and almost $\$ 400$ billion market value. These estimates are based on calculations in Altman and Pompeii (2002) from periodic, not continuous, market calculations and estimates. ${ }^{23}$

On a relative scale, the ratio of supply to demand of distressed and defaulted securities was something like ten to one in both 1990-1991 and also in 2000-2001. Dollarwise, of course, the amount of supply side money dwarfed the demand in both periods. And, as we will show, the price levels of new defaulting securities was relatively very low in both periods - at the start of the 1990's and again at the start of the 2000 decade.

\footnotetext{
${ }^{23}$ Defaulted bonds and bank loans are relatively easy to define and are carefully documented by the rating agencies and others. Distressed securities are defined here as bonds selling at least 1000 basis points over comparable maturity Treasury Bonds (we use the 10-year T-Bond rate as our benchmark). Privately owned securities, primarily
} 


\subsection{Univariate Models}

We begin the discussion of our results with the univariate relationships between recovery rates and the explanatory variables described in the previous section. Table 4 displays the results of the univariate regressions carried out using these variables.

Table 4: Univariate Regressions, 1982-2000

Variables Explaining Annual Recovery Rates on Defaulted Corporate Bonds Coefficients and T-Ratios (in parentheses)

\begin{tabular}{|c|c|c|c|c|c|c|c|c|c|c|}
\hline Regression \# & $(1)$ & (2) & (3) & (4) & (5) & (6) & $(7)$ & $(8)$ & (9) & $(10)$ \\
\hline R-Squared & 0.45 & 0.49 & 0.58 & 0.60 & 0.51 & 0.52 & 0.20 & 0.23 & 0.46 & 0.54 \\
\hline Adj. R-Squared & 0.42 & 0.46 & 0.56 & 0.58 & 0.48 & 0.49 & 0.15 & 0.18 & 0.43 & 0.51 \\
\hline Dependent Variable: & & & & & & & & & & \\
\hline BRR & $\mathrm{X}$ & & $\mathrm{X}$ & & $\mathrm{X}$ & & $\mathrm{x}$ & & $\mathrm{X}$ & \\
\hline $\begin{array}{l}\text { BLRR } \\
\text { Explanatory Variables: }\end{array}$ & & $x$ & & $\mathrm{X}$ & & $\mathrm{x}$ & & $X$ & & $\mathrm{X}$ \\
\hline Constant & $\begin{array}{r}0.51 \\
(17.40)\end{array}$ & $\begin{array}{r}-0.67 \\
(-9.55)\end{array}$ & $\begin{array}{r}0.01 \\
(0.10)\end{array}$ & $\begin{array}{r}-1.94 \\
(-9.12)\end{array}$ & $\begin{array}{r}0.43 \\
(24.01)\end{array}$ & $\begin{array}{r}-0.87 \\
(-19.39)\end{array}$ & $\begin{array}{r}0.49 \\
(12.83)\end{array}$ & $\begin{array}{r}-0.72 \\
(-7.70)\end{array}$ & $\begin{array}{r}0.49 \\
(19.16)\end{array}$ & $\begin{array}{r}-0.71 \\
(-12.01)\end{array}$ \\
\hline BDR & $\begin{array}{r}-2.62 \\
(-3.73)\end{array}$ & $\begin{array}{r}-6.82 \\
(-4.04)\end{array}$ & & & & & & & & \\
\hline BLDR & & & $\begin{array}{r}-0.11 \\
(-4.86)\end{array}$ & $\begin{array}{r}-0.28 \\
(-5.05)\end{array}$ & & & & & & \\
\hline BDRC & & & & & $\begin{array}{r}-2.99 \\
(-4.19)\end{array}$ & $\begin{array}{r}-7.51 \\
(-4.25)\end{array}$ & & & & \\
\hline BOA & & & & & & & $\begin{array}{r}-0.29 \\
(-2.06)\end{array}$ & $\begin{array}{r}-0.76 \\
(-2.23)\end{array}$ & & \\
\hline BDA & & & & & & & & & $\begin{array}{l}-8.53 \\
-3.78\end{array}$ & $\begin{array}{r}-23.16 \\
-4.48\end{array}$ \\
\hline \multicolumn{11}{|l|}{ GDP } \\
\hline \multicolumn{11}{|l|}{ GDPC } \\
\hline \multicolumn{11}{|l|}{ GDPI } \\
\hline \multicolumn{11}{|l|}{ SR } \\
\hline \multicolumn{11}{|l|}{ SRC } \\
\hline Spread & & & & & & & & & & \\
\hline
\end{tabular}


Table 4: Univariate Regressions, 1982-2000 - continued

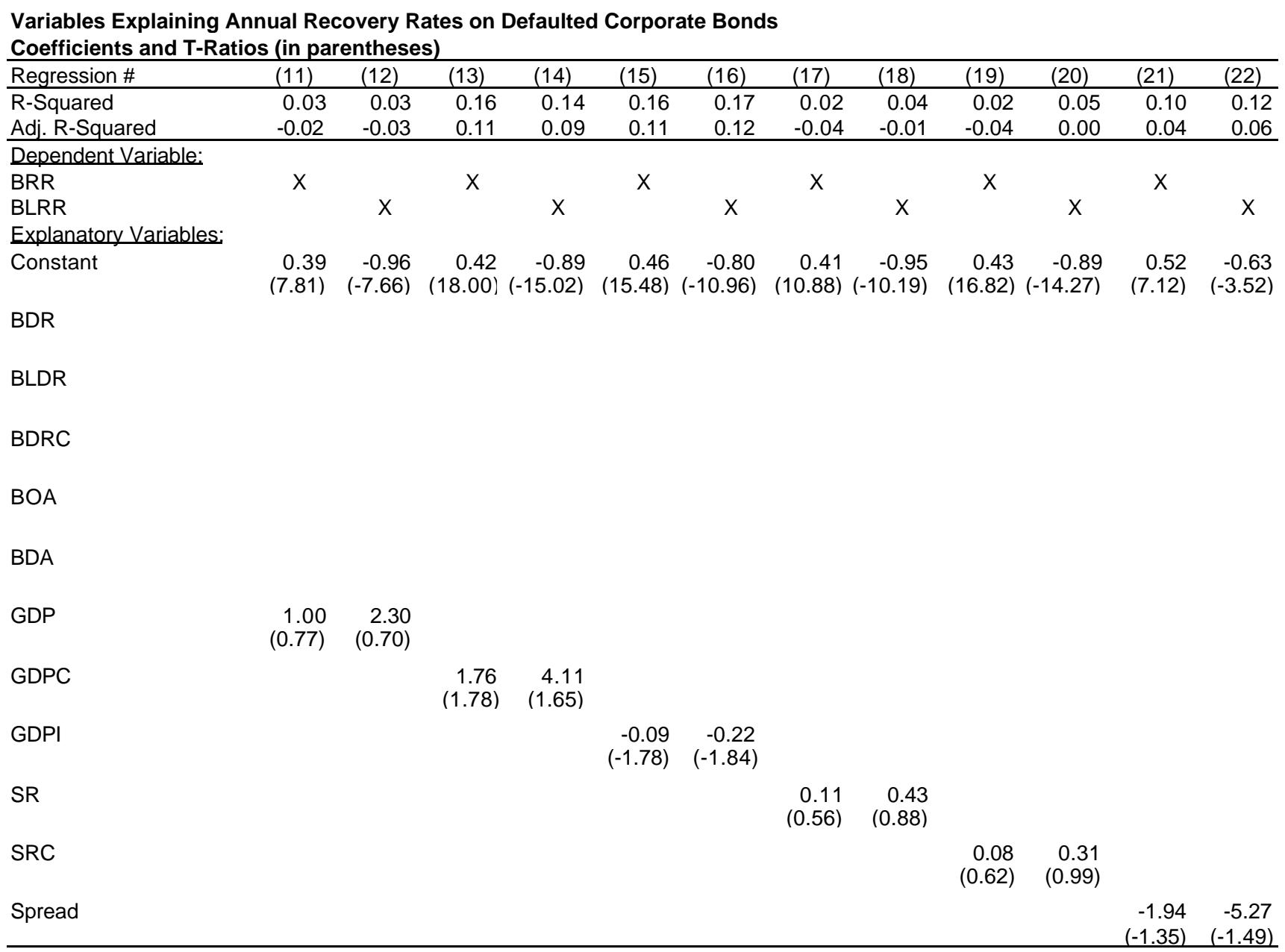

These univariate regressions, and the multivariate regressions discussed in the following section, were calculated using both the recovery rate $(\boldsymbol{B R R})$ and the natural $\log (\boldsymbol{B L R R})$ of the recovery rate as the dependent variables. Both results are displayed in Table 4, as signified by an " $\mathrm{x}$ " in the corresponding row.

We examine the simple relationship between bond recovery rates and bond default rates for the period 1982-2000 (there simply are too few default observations in the 1978-1981 period). Table 4 and Figure 3 show several regressions between the two fundamental variables and we find that one can explain about $45 \%$ of the variation in the annual recovery rate with the level of default rates (this is the linear model, regression 1) and as much as $60 \%$, or more, with 
the quadratic and power ${ }^{24}$ relationships (regressions 3 and 4). Hence, our basic thesis that the rate of default is a massive indicator of the likely average recovery rate amongst corporate bonds appears to be substantiated ${ }^{25}$.

The other univariate results show the correct sign for each coefficient, but not all of the relationships are significant. $\boldsymbol{B D R C}$ is highly negatively correlated with recovery rates, as shown by the very significant t-ratios, although the $\mathrm{t}$-ratios and $\mathrm{R}$-squared values are not as significant as those for $\boldsymbol{B L D R}$. BOA and $\boldsymbol{B D A}$ are, as expected, both negatively correlated with recovery rates with $\boldsymbol{B D A}$ being more highly negatively correlated than $\boldsymbol{B O A}$ on a univariate basis. Macroeconomic variables did not explain as much of the variation in recovery rates as the corporate bond market variables explained; we will come back to these relationships in the next paragraphs.

${ }^{24}$ The power relationship $\left(\boldsymbol{B R R}=\exp \left[\mathrm{b}_{0}\right] \times \boldsymbol{B D D \boldsymbol { R } ^ { \mathrm { b } 1 }}\right)$ can be estimated using the following equivalent equation: $\boldsymbol{B} \boldsymbol{L R \boldsymbol { R }}$ $=\mathrm{b}_{0}+\mathrm{b}_{1} \times \boldsymbol{B} \boldsymbol{L D} \boldsymbol{R}$ ("power model").

${ }^{25}$ Such an impression is strongly supported by a $-80 \%$ rank correlation coefficient between BDR and BRR (computed over the 1982-2001 period; however, the same value holds for the reduced 1987-2000 window used in the following paragraphs). Note that rank correlations represent quite a robust indicator, since they do not depend upon any specific functional form (e.g., log, quadratic, power, etc.). 


\section{Recovery Rate/Default Rate Association}

Altman Defaulted Bonds Data Set (1982-2000)

Dollar Weighted Average Recovery Rates to Dollar Weighted Average Default Rates

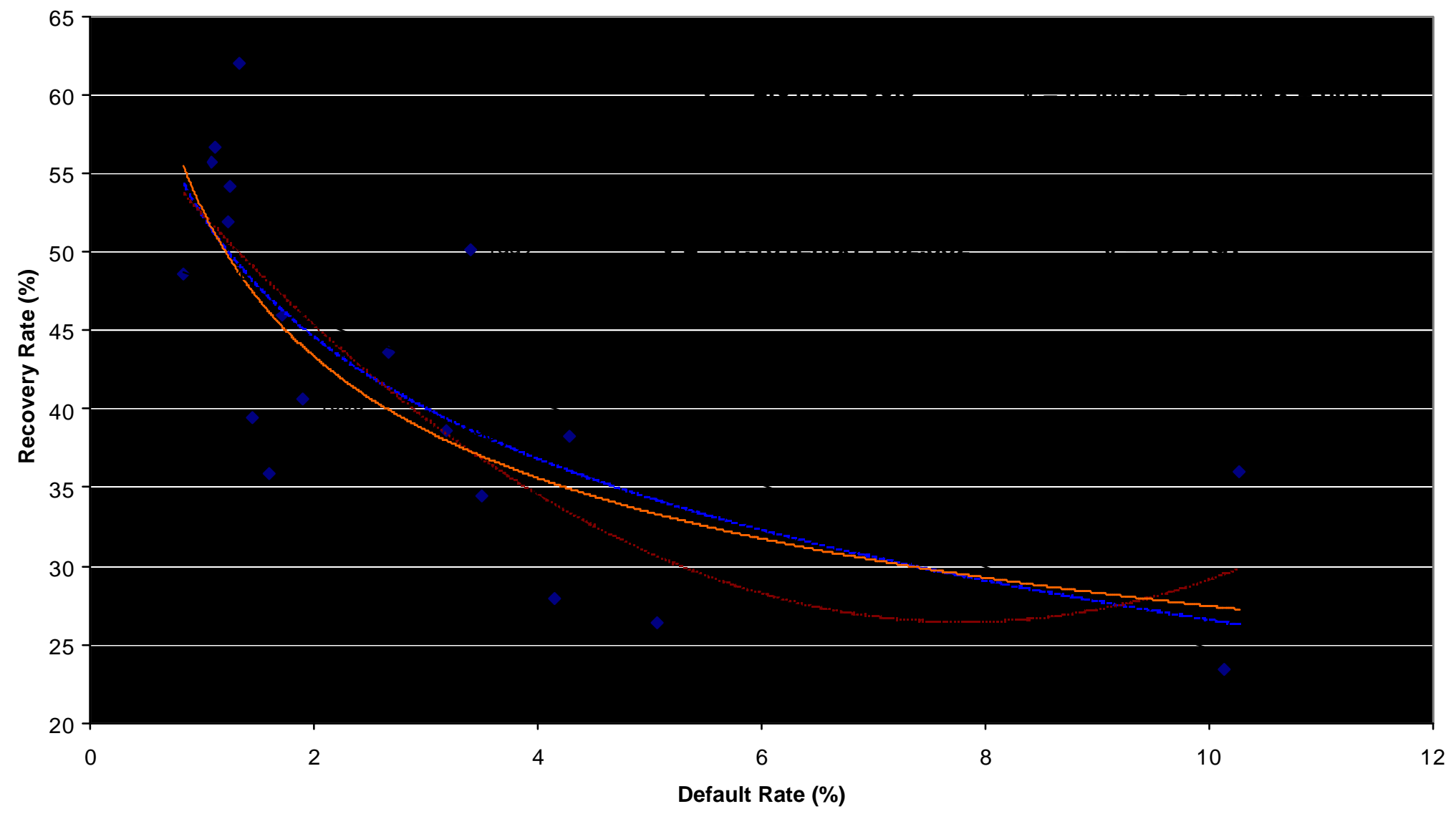





\subsection{Multivariate Models}

We now specify models to explain recovery rates that are somewhat more complex by including several additional variables to the important default rate measure. The basic structure of our most successful models is:

\section{$B R R=f(B D R, B D R C, B O A$ or BDA, BIR $)$}

Some macroeconomic variables will be added to this basic structure, to test their effect on recovery rates.

We have constructed two simple regression structures in order to explain recovery rate results and to predict 2001 rates. One set is for the longer 1982-2000 period and the other is for the 1987-2000 period $^{26}$. Both sets involve linear and log-linear structures for the two key variables - recovery rates (dependent) and default rates (explanatory) with the log-linear relationships somewhat more significant. These results appear in Table 5 and 6; regressions 1 through 4 build the "basic models", while macro variables are added in the following rows.

\subsection{The Results for 1987-2000}

Table 5 regressions 1-4 present our results for the "basic" models. Note that most, but not all, of the variables are quite significant based on their tratios. The overall accuracy of the fit goes from $84 \%$ (76\% adjusted R-square) for the strictly absolute value of all variables (regression 1) to $88 \%$ (83\% adjusted) when the dependent variable (regression 2) is specified in natural logs, to the same $88 \%$ (regression 3) when only the primary independent variable (default rates $-\boldsymbol{B} \boldsymbol{L D R}$ ) is specified in natural $\operatorname{logs}$ to as much as $91 \%$ (unadjusted) and $87 \%$ (adjusted) Rsquares where both the primary dependent $(\boldsymbol{B L R R})$ and explanatory variable $(\boldsymbol{B L D R})$ are expressed in natural logs (regression 4).

\footnotetext{
${ }^{26}$ As concerns the BIR variable, univariate regressions were carried out over the 1987-2000 period, as this index is not available in previous years: we found positive coefficients both for BRR and its log, with t-test values of about 2.3 .
} 
Table 5: Multivariate Regressions 1987 -2000

Variables Explaining Annual Recovery Rates on Defaulted Corporate Bonds

Coefficients and T-Ratios (in parentheses)

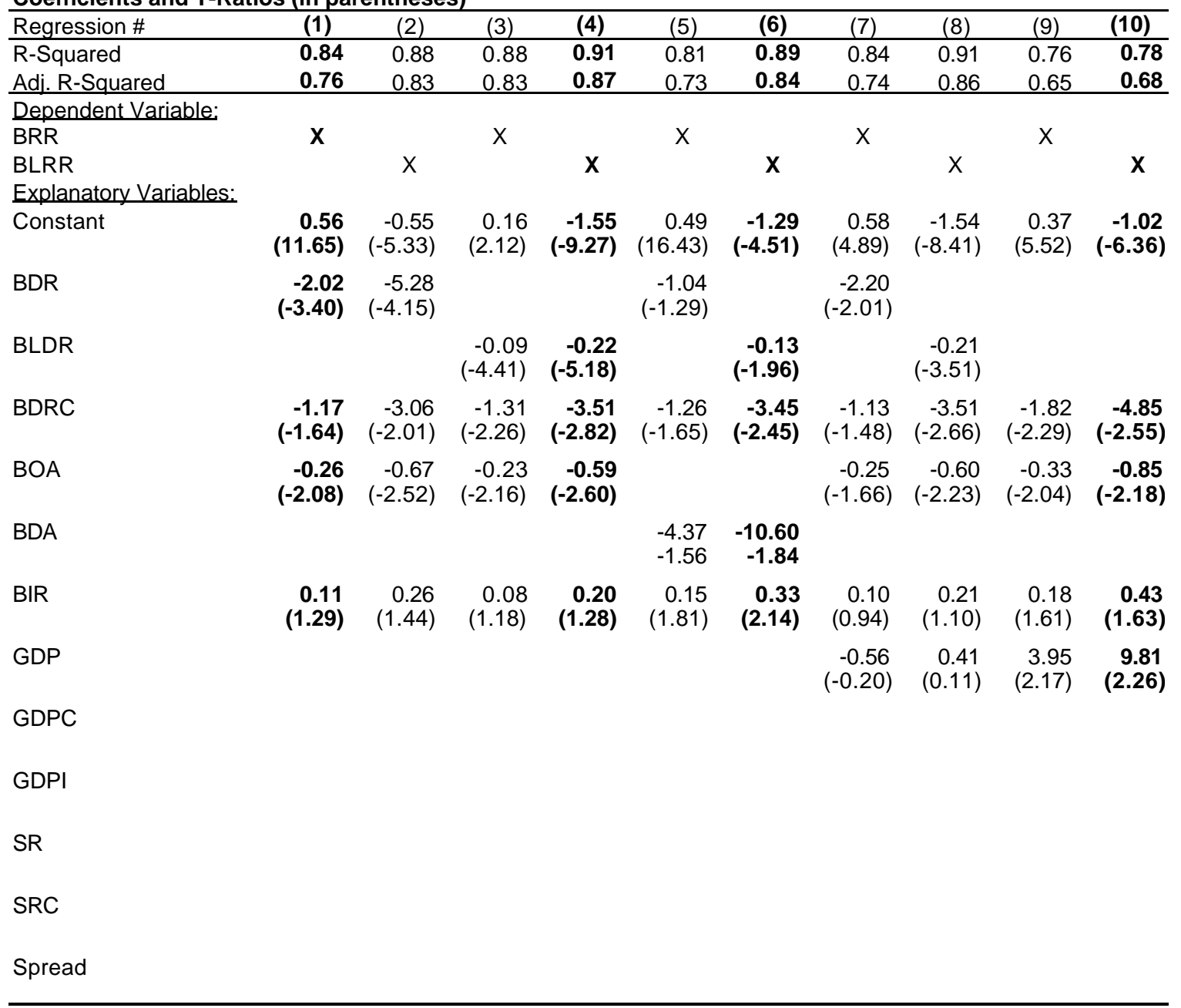


Table 5: Multivariate Regressions 1987 -2000 - Continued

Văriables Explaining Annüal Recovery Rates on Defaulted Corporate Bonds

Coefficients and T-Ratios (in parentheses)

\begin{tabular}{|c|c|c|c|c|c|c|c|c|c|c|}
\hline Regression \# & (11) & (12) & (13) & (14) & (15) & (16) & (17) & (18) & (19) & (20) \\
\hline R-Squared & 0.85 & 0.92 & 0.84 & 0.91 & 0.84 & 0.93 & 0.84 & 0.92 & 0.85 & 0.92 \\
\hline Adj. R-Squared & 0.75 & 0.86 & 0.74 & 0.86 & 0.74 & 0.88 & 0.74 & 0.87 & 0.75 & 0.87 \\
\hline \multicolumn{11}{|l|}{ Dependent Variable: } \\
\hline BRR & $x$ & & $X$ & & $x$ & & $x$ & & $x$ & \\
\hline BLRR & & $x$ & & $x$ & & $X$ & & $x$ & & $x$ \\
\hline \multicolumn{11}{|l|}{ Explanatory Variables: } \\
\hline Constant & $\begin{array}{r}0.56 \\
(11.29)\end{array}$ & $\begin{array}{r}-1.56 \\
(-8.91)\end{array}$ & $\begin{array}{r}0.56 \\
(10.60)\end{array}$ & $\begin{array}{r}-1.56 \\
(-7.17)\end{array}$ & $\begin{array}{r}0.55 \\
(10.23)\end{array}$ & $\begin{array}{r}-1.54 \\
(-9.54)\end{array}$ & $\begin{array}{r}0.56 \\
(11.03)\end{array}$ & $\begin{array}{r}-1.53 \\
(-8.93)\end{array}$ & $\begin{array}{r}0.49 \\
(4.50)\end{array}$ & $\begin{array}{r}-2.15 \\
(-3.28)\end{array}$ \\
\hline BDR & $\begin{array}{r}-2.16 \\
(-3.39)\end{array}$ & & $\begin{array}{r}-2.06 \\
(-2.88)\end{array}$ & & $\begin{array}{r}-1.98 \\
(-3.07)\end{array}$ & & $\begin{array}{r}-2.05 \\
(-3.22)\end{array}$ & & $\begin{array}{r}-3.71 \\
(-1.39)\end{array}$ & \\
\hline BLDR & & $\begin{array}{r}-0.22 \\
(-5.00)\end{array}$ & & $\begin{array}{r}-0.22 \\
(-4.44)\end{array}$ & & $\begin{array}{r}-0.21 \\
(-4.98)\end{array}$ & & $\begin{array}{r}-0.21 \\
(-4.95)\end{array}$ & & $\begin{array}{r}-0.32 \\
(-2.73)\end{array}$ \\
\hline BDRC & $\begin{array}{r}-1.64 \\
(-1.70)\end{array}$ & $\begin{array}{r}-4.23 \\
(-2.36)\end{array}$ & $\begin{array}{r}-1.17 \\
(-1.55)\end{array}$ & $\begin{array}{r}-3.52 \\
(-2.65)\end{array}$ & $\begin{array}{r}-1.20 \\
(-1.58)\end{array}$ & $\begin{array}{r}-3.73 \\
(-3.08)\end{array}$ & $\begin{array}{r}-1.12 \\
(-1.44)\end{array}$ & $\begin{array}{r}-3.74 \\
(-2.87)\end{array}$ & $\begin{array}{r}-0.79 \\
(-0.85)\end{array}$ & $\begin{array}{r}-3.27 \\
(-2.56)\end{array}$ \\
\hline BOA & $\begin{array}{r}-0.25 \\
(-1.98)\end{array}$ & $\begin{array}{r}-0.58 \\
(-2.44)\end{array}$ & $\begin{array}{r}-0.26 \\
(-1.90)\end{array}$ & $\begin{array}{r}-0.58 \\
(-2.37)\end{array}$ & $\begin{array}{r}-0.26 \\
(-1.98)\end{array}$ & $\begin{array}{r}-0.61 \\
(-2.78)\end{array}$ & $\begin{array}{r}-0.26 \\
(-1.98)\end{array}$ & $\begin{array}{r}-0.58 \\
(-2.48)\end{array}$ & $\begin{array}{r}-0.29 \\
(-2.11)\end{array}$ & $\begin{array}{r}-0.58 \\
(-2.57)\end{array}$ \\
\hline \multicolumn{11}{|l|}{ BDA } \\
\hline BIR & $\begin{array}{r}0.08 \\
(0.87)\end{array}$ & $\begin{array}{r}0.16 \\
(0.91)\end{array}$ & $\begin{array}{r}0.11 \\
(1.21)\end{array}$ & $\begin{array}{r}0.20 \\
(1.20)\end{array}$ & $\begin{array}{r}0.10 \\
(1.16)\end{array}$ & $\begin{array}{r}0.17 \\
(1.14)\end{array}$ & $\begin{array}{r}0.12 \\
(1.23)\end{array}$ & $\begin{array}{r}0.15 \\
(0.89)\end{array}$ & $\begin{array}{r}0.02 \\
(0.16)\end{array}$ & $\begin{array}{r}0.02 \\
(0.10)\end{array}$ \\
\hline \multicolumn{11}{|l|}{ GDP } \\
\hline GDPC & $\begin{array}{r}-1.33 \\
(-0.75)\end{array}$ & $\begin{array}{r}-1.87 \\
(-0.58)\end{array}$ & & & & & & & & \\
\hline GDPI & & & $\begin{array}{r}0.01 \\
(0.13)\end{array}$ & $\begin{array}{r}0.01 \\
(0.09)\end{array}$ & & & & & & \\
\hline SR & & & & & $\begin{array}{r}0.03 \\
(0.29)\end{array}$ & $\begin{array}{r}0.26 \\
(1.31)\end{array}$ & & & & \\
\hline SRC & & & & & & & $\begin{array}{r}-0.02 \\
(-0.27)\end{array}$ & $\begin{array}{r}0.13 \\
(0.80)\end{array}$ & & \\
\hline Spread & & & & & & & & & $\begin{array}{r}2.70 \\
(0.65) \\
\end{array}$ & $\begin{array}{r}4.55 \\
(0.95) \\
\end{array}$ \\
\hline
\end{tabular}


Table 6: Multivariate Regressions 1982 -2000

Variables Explaining Annual Recovery Rates on Defaulted Corporate Bonds

Coefficients and T-Ratios (in parentheses)

\begin{tabular}{|c|c|c|c|c|c|c|c|c|c|c|}
\hline Regression \# & (1) & (2) & (3) & (4) & (5) & (6) & (7) & (8) & (9) & $(10)$ \\
\hline R-Squared & 0.77 & 0.82 & 0.83 & 0.87 & 0.74 & 0.84 & 0.78 & 0.88 & 0.66 & 0.68 \\
\hline Adj. R-Squared & 0.73 & 0.79 & 0.80 & 0.84 & 0.69 & 0.81 & 0.71 & 0.85 & 0.59 & 0.62 \\
\hline $\begin{array}{l}\text { Dependent Variable: } \\
\text { BRR }\end{array}$ & $\mathbf{X}$ & & $\mathrm{x}$ & & $\mathrm{X}$ & & $x$ & & $x$ & \\
\hline $\begin{array}{l}\text { BLRR } \\
\text { Explanatory Variables: }\end{array}$ & & $\mathrm{X}$ & & $\mathbf{x}$ & & $\mathbf{X}$ & & $X$ & & $\mathbf{x}$ \\
\hline Constant & $\begin{array}{r}0.53 \\
(20.03)\end{array}$ & $\begin{array}{r}-0.61 \\
(-10.46)\end{array}$ & $\begin{array}{r}0.20 \\
(2.75)\end{array}$ & $\begin{array}{r}-1.46 \\
(-9.17)\end{array}$ & $\begin{array}{r}0.49 \\
(21.99)\end{array}$ & $\begin{array}{r}-1.20 \\
(-5.01)\end{array}$ & $\begin{array}{r}0.54 \\
(12.89)\end{array}$ & $\begin{array}{r}-1.55 \\
(-9.45)\end{array}$ & $\begin{array}{r}0.46 \\
(13.06)\end{array}$ & $\begin{array}{r}-0.79 \\
(-9.29)\end{array}$ \\
\hline BDR & $\begin{array}{r}-1.62 \\
(-3.02)\end{array}$ & $\begin{array}{r}-4.36 \\
(-3.69)\end{array}$ & & & $\begin{array}{r}-0.69 \\
(-0.94)\end{array}$ & & $\begin{array}{r}-1.75 \\
(-2.71)\end{array}$ & & & \\
\hline BLDR & & & $\begin{array}{r}-0.07 \\
(-4.16)\end{array}$ & $\begin{array}{r}-0.19 \\
(-4.74)\end{array}$ & & $\begin{array}{r}-0.11 \\
(-1.96)\end{array}$ & & $\begin{array}{r}-0.23 \\
(-4.92)\end{array}$ & & \\
\hline BDRC & $\begin{array}{r}-2.02 \\
(-3.49)\end{array}$ & $\begin{array}{r}-4.92 \\
(-3.87)\end{array}$ & $\begin{array}{r}-1.88 \\
(-3.75)\end{array}$ & $\begin{array}{r}-4.67 \\
(-4.20)\end{array}$ & $\begin{array}{r}-2.12 \\
(-3.46)\end{array}$ & $\begin{array}{r}-4.81 \\
(-3.96)\end{array}$ & $\begin{array}{r}-2.03 \\
(-3.40)\end{array}$ & $\begin{array}{r}-4.64 \\
(-4.34)\end{array}$ & $\begin{array}{r}-2.63 \\
(-3.98)\end{array}$ & $\begin{array}{r}-6.60 \\
(-4.17)\end{array}$ \\
\hline BOA & $\begin{array}{r}-0.22 \\
(-2.72)\end{array}$ & $\begin{array}{r}-0.58 \\
(-3.33)\end{array}$ & $\begin{array}{r}-0.19 \\
(-2.67)\end{array}$ & $\begin{array}{r}-0.51 \\
(-3.27)\end{array}$ & & & $\begin{array}{r}-0.20 \\
(-2.31)\end{array}$ & $\begin{array}{r}-0.40 \\
(-2.42)\end{array}$ & $\begin{array}{r}-0.26 \\
(-2.56)\end{array}$ & $\begin{array}{r}-0.69 \\
(-2.83)\end{array}$ \\
\hline BDA & & & & & $\begin{array}{r}-4.94 \\
(-2.20)\end{array}$ & $\begin{array}{l}-11.73 \\
(-2.55)\end{array}$ & & & & \\
\hline GDP & & & & & & & $\begin{array}{r}-0.32 \\
(-0.37)\end{array}$ & $\begin{array}{r}-2.42 \\
(-1.50)\end{array}$ & $\begin{array}{r}0.87 \\
(0.98)\end{array}$ & $\begin{array}{r}2.06 \\
(0.97)\end{array}$ \\
\hline \multicolumn{11}{|l|}{ GDPC } \\
\hline \multicolumn{11}{|l|}{ GDPI } \\
\hline \multicolumn{11}{|l|}{ SR } \\
\hline \multicolumn{11}{|l|}{ SRC } \\
\hline Spread & & & & & & & & & & \\
\hline
\end{tabular}


Table 6: Multivariate Regressions 1982 -2000 - continued

Variables Explaining Annual Recovery Rates on Defaulted Corporate Bonds

Coefficients and T-Ratios (in parentheses)

\begin{tabular}{|c|c|c|c|c|c|c|c|c|c|c|}
\hline Regression \# & $(11)$ & (12) & (13) & (14) & (15) & (16) & (17) & $(18)$ & (19) & (20) \\
\hline R-Squared & 0.78 & 0.88 & 0.77 & 0.87 & 0.78 & 0.89 & 0.78 & 0.89 & 0.71 & 0.79 \\
\hline Adi. R-Squared & 0.71 & 0.85 & 0.71 & 0.83 & 0.72 & 0.86 & 0.71 & 0.86 & 0.66 & 0.75 \\
\hline $\begin{array}{l}\text { Dependent Variable: } \\
\text { BRR }\end{array}$ & X & & $x$ & & $X$ & & $X$ & & $X$ & \\
\hline $\begin{array}{l}\text { BLRR } \\
\text { Explanatory Variables: }\end{array}$ & & $X$ & & $X$ & & $x$ & & $X$ & & $x$ \\
\hline Constant & $\begin{array}{r}0.53 \\
(19.38)\end{array}$ & $\begin{array}{r}-1.51 \\
(-9.54)\end{array}$ & $\begin{array}{r}0.53 \\
(19.25)\end{array}$ & $\begin{array}{r}-1.51 \\
(-7.79)\end{array}$ & $\begin{array}{r}0.52 \\
(15.95)\end{array}$ & $\begin{array}{r}-1.47 \\
(-9.88)\end{array}$ & $\begin{array}{r}0.53 \\
(18.81)\end{array}$ & $\begin{array}{r}-1.47 \\
(-9.93)\end{array}$ & $\begin{array}{r}0.39 \\
(6.29)\end{array}$ & $\begin{array}{r}-2.11 \\
(-5.32)\end{array}$ \\
\hline BDR & $\begin{array}{l}-1.66 \\
(-2.95)\end{array}$ & & $\begin{array}{r}-1.68 \\
(-2.66)\end{array}$ & $\begin{array}{r}-0.20 \\
(-4.30)\end{array}$ & $\begin{array}{r}-1.56 \\
(-2.79)\end{array}$ & & $\begin{array}{r}-1.60 \\
(-2.88)\end{array}$ & & $\begin{array}{r}-3.80 \\
(-2.69)\end{array}$ & \\
\hline BLDR & & $\begin{array}{r}-0.20 \\
(-5.10)\end{array}$ & & & & $\begin{array}{r}-0.18 \\
(-4.76)\end{array}$ & & $\begin{array}{r}-0.18 \\
(-5.03)\end{array}$ & & $\begin{array}{r}-0.28 \\
(-3.78)\end{array}$ \\
\hline BDRC & $\begin{array}{r}-2.15 \\
(-3.10)\end{array}$ & $\begin{array}{r}-5.53 \\
(-4.48)\end{array}$ & $\begin{array}{r}-2.04 \\
(-3.38)\end{array}$ & $\begin{array}{r}-4.74 \\
(-4.11)\end{array}$ & $\begin{array}{r}-2.06 \\
(-3.47)\end{array}$ & $\begin{array}{r}-4.83 \\
(-4.63)\end{array}$ & $\begin{array}{r}-2.07 \\
(-3.44)\end{array}$ & $\begin{array}{r}-4.89 \\
(-4.70)\end{array}$ & $\begin{array}{r}-1.32 \\
(-1.60)\end{array}$ & $\begin{array}{r}-4.03 \\
(-2.69)\end{array}$ \\
\hline BOA & $\begin{array}{r}-0.21 \\
(-2.58)\end{array}$ & $\begin{array}{r}-0.48 \\
(-3.14)\end{array}$ & $\begin{array}{r}-0.22 \\
(-2.63)\end{array}$ & $\begin{array}{r}-0.50 \\
(-3.15)\end{array}$ & $\begin{array}{r}-0.22 \\
(-2.66)\end{array}$ & $\begin{array}{r}-0.51 \\
(-3.52)\end{array}$ & $\begin{array}{r}-0.20 \\
(-2.39)\end{array}$ & $\begin{array}{r}-0.43 \\
(-2.85)\end{array}$ & & \\
\hline \multicolumn{11}{|l|}{ BDA } \\
\hline \multicolumn{11}{|l|}{ GDP } \\
\hline GDPC & $\begin{array}{r}-0.24 \\
(-0.35)\end{array}$ & $\begin{array}{r}-1.84 \\
(-1.43)\end{array}$ & & & & & & & & \\
\hline GDPI & & & $\begin{array}{r}0.01 \\
(0.19)\end{array}$ & $\begin{array}{l}0.03 \\
(0.46)\end{array}$ & & & & & & \\
\hline SR & & & & & $\begin{array}{r}0.06 \\
(0.61)\end{array}$ & $\begin{array}{r}0.33 \\
(1.79)\end{array}$ & & & & \\
\hline SRC & & & & & & & $\begin{array}{r}0.04 \\
(0.50)\end{array}$ & $\begin{array}{r}0.23 \\
(1.85)\end{array}$ & & \\
\hline Spread & & & & & & & & & $\begin{array}{r}3.30 \\
(1.63) \\
\end{array}$ & $\begin{array}{r}3.77 \\
(1.33) \\
\end{array}$ \\
\hline
\end{tabular}


Figure 4 - Actual vs. Estimated Recovery Rates on Defaulted Corporate Bonds

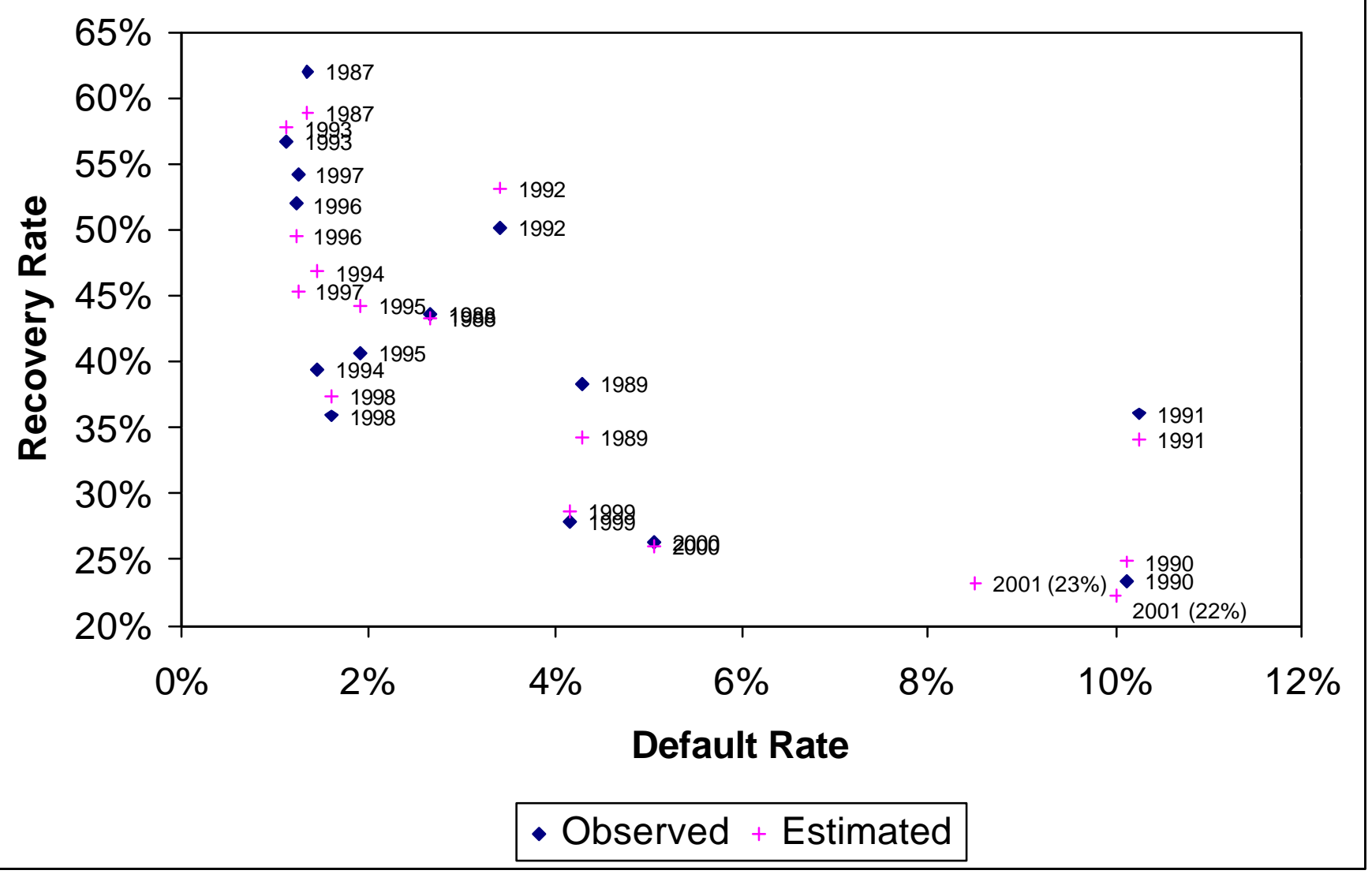


The actual model with the highest explanatory power and lowest "error" rates is the power model ${ }^{27}$ in regression 4 of Table 5 . We see that all of the four explanatory variables have the expected sign (negative for $\boldsymbol{B L D R}, \boldsymbol{B D R C}$, and $\boldsymbol{B O A}$ and positive for $\boldsymbol{B I R}$ ) and are significant at the $5 \%$ or $1 \%$ level, except for the Defaulted Bond Index $(\boldsymbol{B I R})$ which has the appropriate sign (+) but a less meaningful tratio ${ }^{28}$. BLDR and $\boldsymbol{B D R C}$ are extremely significant, showing that the level and change in the default rate are highly important explanatory variables for recovery rates. Indeed the variables $\boldsymbol{B D R}$ (and $\boldsymbol{B} \boldsymbol{L D R}$ ) explain up to 57\% (unadjusted) and 53\% (adjusted) of the variation in $\boldsymbol{B R} \boldsymbol{R}$ simply based on a linear or log-linear association. The size of the high yield market also performs very well and adds about $8 \%$ to the explanatory power of the model. When we substitute $\boldsymbol{B D A}$ for $\boldsymbol{B O A}$, the explanatory power of multivariate model drops somewhat to 0.89 (unadjusted) and 0.84 (adjusted) R-squared. Still, the sign of BDA is correct $(+)$ and the tratio is quite high (1.84 - see regression 6 of Table 5). Indeed, on a univariate basis, $\boldsymbol{B D A}$ is actually far more significant than $\boldsymbol{B O A}$ (see Table 4).

Figure 4 shows, graphically, the results for the Table 5 regression 4 structure, by comparing the actual Recovery Rate vs. the estimated rates (designated by a "+" sign) for 19872000. Note the extremely close accuracy in almost every year between the actual and estimated rates. Figure 4 also shows how our multivariate regressions can be used to estimate the 2001 expected recovery rate, given certain assumptions about the independent variables and the time frame for the regressions. Specifically, assuming default rates for 2001 of $8.5 \%$ (or $10 \%)^{29}$, a change in default rates compared to 2000 's $5.1 \%$ of $3.44 \%$ (or $4.94 \%$ ), a BIR of $18.0 \%$ (the rate of return as of August, 2001), a BOA of $\$ 630$ billion (midyear 2001) or a BDA of $8.5 \%-10 \%$ of the high yield bond market, this results in an estimated recovery rate of 22-23\% When we substitute BDA for BOA, the estimates for 2001 recovery rates are $20 \%$ assuming an $8.5 \%$ default rate and $18 \%$ assuming a $10 \%$ default rate. The actual recovery rate in 2001 was $25 \%$ (including one large unique bankruptcy - FINOVA - or 21\% - without FINOVA - see Altman and Arman, 2002); so our estimates were very close to the actual.

\footnotetext{
${ }^{27}$ Like its univariate cousin, the multivariate power model can be written using logs. E.g., $\boldsymbol{B} \boldsymbol{L} \boldsymbol{R} \boldsymbol{R}=\mathrm{b}_{0}+\mathrm{b}_{1} \times \boldsymbol{B} \boldsymbol{L D} \boldsymbol{R}+$ $\mathrm{b}_{2} \times \boldsymbol{B D} \boldsymbol{R} \boldsymbol{C}+\mathrm{b}_{3} \times \boldsymbol{B I} \boldsymbol{R}+\mathrm{b}_{4} \times \boldsymbol{B} \boldsymbol{O A}$ becomes $\boldsymbol{B} \boldsymbol{R} \boldsymbol{R}=\exp \left[\mathrm{b}_{0}\right] \times \boldsymbol{B D} \boldsymbol{R}^{\mathrm{b} 1} \times \exp \left[\mathrm{b}_{2} \times \boldsymbol{B D} \boldsymbol{R} \boldsymbol{C}+\mathrm{b}_{3} \times \boldsymbol{B I} \boldsymbol{R}+\mathrm{b}_{4} \times \boldsymbol{B} \boldsymbol{O A}\right]$ and takes its name from BDR being raised to the power of its coefficient.

${ }^{28} \boldsymbol{B I R}$ s t-ratio is only significant at the 0.25 level. Without the $\boldsymbol{B I R}$ variable, the R-squared measures are slightly lower at $90 \%$ (unadjusted ) and $87 \%$ (adjusted). On a univariate basis, the $\boldsymbol{B I R}$ is significant with a t-ratio of 2.34 and explains $25 \%$ of the variation in $\boldsymbol{B R} \boldsymbol{R}$.

29 These were Altman's (8.5\%) and Moody's (10.0\%) default rates estimates for 2001 made at the beginning of the year. More recent estimates are higher given the impact from the September 11, 2001 tragedy, and the final default rate in 2001 was $9.8 \%$.
} 


\subsection{The Results for 1982-2000 and Autocorrelation Tests}

Table 6 regressions 1-4 show the same regression structures as Table 5 regressions 1-4, only the sample period is for 1982-2000 and the models do not include the BIR variable. Regression 1 of Table 6 shows that all three explanatory variables are significant at the $1 \%$ or $5 \%$ level with high t-ratios. All have the correct sign, indicating that recovery rates are negatively correlated with default rates, the change in default rates and the size of the high yield bond market. The R-squared of this straightforward, linear regression is 0.77 (0.73 adjusted). Finally, as with the shorter time period, the highest R-squared explanatory model for the longer time period uses the log specification for both $\boldsymbol{B} \boldsymbol{L R} \boldsymbol{R}$ and $\boldsymbol{B} \boldsymbol{L D R}$, which raises the unadjusted Rsquared to 0.87 (Table 6, regression 4). These results are slightly lower than for the longer time frame (1982-2000), but still very meaningful. Hence, we are quite optimistic that the variable set, while probably not optimal, can be used to explain and predict recovery rates in the corporate defaulted bond market.

We do observe a few clusters of recovery rates in such years as 1994-1995,1996-1997 and 1999-2000 (see Figures 3 and 4) so we test for autocorrelation of the residuals. The resulting Durbin-Watson statistics did not show any autocorrelation problems and either reject the assumption or find the tests inconclusive.

\subsection{Macroeconomic Variables}

While we are pleased with the accuracy and explanatory power of the regressions described above, we were not very successful in our attempts to include several fundamental macroeconomic factors. We assessed these factors both on a univariate as well as a value-added basis for our multivariate structures. We are somewhat surprised by the low contributions of these variables since there are several models that have been constructed that utilize macrovariables, apparently significantly, in explaining annual default rates ${ }^{30}$.

Despite the fact that the growth rate in annual GDP is significantly negatively correlated with the bond default rate, i.e., -0.67 for the period 1987-2000 and -0.50 for $1982-2000$, the univariate correlation between recovery rates $(\boldsymbol{B R R})$ and GDP growth is relatively low (see Table 4); the sign (+) is appropriate, however. Note that the GDP growth variable has a -0.02

\footnotetext{
${ }^{30}$ See e.g. Fons (1991), Jonsson and Fridson (1996), Moody’s (1999), Fridson, Garman, and Wu (1997), Helwege and Kleiman (1997).
} 
and -0.03 adjusted Rsquared with $\boldsymbol{B R} \boldsymbol{R}$ and $\boldsymbol{B} \boldsymbol{L} \boldsymbol{R} \boldsymbol{R}$ (regressions 11 and 12), and a positive but not very significant relationship with recovery rates (R-squared $0.14-0.16$ unadjusted) when we utilize the change in GDP growth (GDPC, regressions 13 and 14).

Furthermore, when we introduce $\boldsymbol{G D P}$ and $\boldsymbol{G D P C}$ to our existing multivariate structures (Tables 5 and 6), not only are they not significant, but they have a counterintuitive sign (negative). The news is not all bad with respect to the multivariate contribution of the GDP variable. When we substitute $\boldsymbol{G D P}$ for $\boldsymbol{B D} \boldsymbol{R}$ in our most successful regressions (see Tables 5 and 6, regressions 9 and 10), we do observe that GDP is significant at .05 level and the sign (+) is correct.

$$
B R R=f(G D P, B D R C, B I R, B O A)
$$

explains 0.76 of $\boldsymbol{B R} \boldsymbol{R}$ and 0.78 of $\boldsymbol{B L R R}$. This compares to 0.84 and 0.88 when we use $\boldsymbol{B D \boldsymbol { R }}$ instead of $\boldsymbol{G D P}$. No doubt, the high negative correlation (-0.67) between $\boldsymbol{G D P}$ and $\boldsymbol{B D R}$ eliminates the possibility of using both in the same multivariate structure.

To try and circumvent this problem, we used a technique similar to Helwege and Kleiman (1997): they postulate that, while a change in GDP of say $1 \%$ or $2 \%$ was not very meaningful in explaining default rates when the base year was in a strong economic growth period, the same change was meaningful when the new level was in a weak economy. Following their approach, we built a dummy variable (GDPI) which takes the value of 1 when GDP grows at less than $1.5 \%$ and 0 otherwise.

Table 4 shows the univariate $\boldsymbol{G D P I}$ results, while Table 5 and Table 6 (regression 14) add the "dummy" variable $\boldsymbol{G D P I}$ to the "power" models discussed earlier. Note that the univariate results show a somewhat significant relationship with the appropriate sign (negative). When the economy grows less than $1.5 \%$, we find that this macroeconomic indicator explains about 0.16 to 0.17 (unadjusted) and 0.11 and 0.12 (adjusted) of the change in recovery rates. The multivariate model with $\boldsymbol{G D P I}$, however, does not add any value to our already very high explanatory power and the sign (+) now is not appropriate. No doubt, the fact that GDP growth is highly correlated with default rates, our primary explanatory variable, impacts the significance and sign of the GDP indicator (GDPI) in our multivariate model.

We also postulated that the return of the stock market could impact prices of defaulting bonds in that the stock market represented investor expectations about the future. Table 5 and 6 regressions 15-18 show the association between the annual S\&P 500 Index stock return (SR) 
(and its change, $\boldsymbol{S R C}$ ) and recovery rates. Note the extremely low univariate R-squared measures and the insignificant t-ratios in the multivariate model, despite the appropriate signs.

\section{The LGD/PD link and the procyclicality effects}

Our findings also have implications for the issue of procyclicality. Procyclicality involves the regulatory capital impact for expected and unexpected losses based on the rating distribution of bank portfolios. Since average ratings and default rates are sensitive to business cycle effects, this makes the new internal ratings-based approach to regulatory capital more dependent on the cycle, increasing capital charges, and limiting credit supply, right when the economy is slowing. Since we found a significant correlation between macroeconomic measures and bond rates/defaults, we might expect that low recovery rates when defaults are high would exacerbate bank loan losses (LGD) in those periods ${ }^{31}$.

When banks adopting the so-called "advanced" IRB approach are free to estimate their own severity rates, with some constraints, they might tend to adjust these estimates according to the economic cycle. As default rates increase, and ratings worsen, LGDs would be revised upwards, making Basel capital even more procyclical than expected.

To assess the impact of such a mechanism, we carry out a simulation based on the evolution over a 20-year period of a standard portfolio of bank loans ${ }^{32}$. The initial composition was chosen arbitrarily, based upon some estimates carried out by the Bank of Italy on a sample of Italian banks ${ }^{33}$ (Marullo-Reedtz, 2000). All loans are assumed to have a 3-year maturity.

From 1981 until 2000, the bank's portfolio mix changes accordingly to S\&P transition matrices $^{34}$ (based on static pools); rates on new loans are revised to compensate for their changes in riskiness, yet margins earned on "old loans" remain unchanged (since the loans have a threeyear maturity, this means that only $1 / 3$ of the loans can be re-priced). Losses emerge according

\footnotetext{
${ }^{31}$ Note that we do not find much of a relationship between GDP growth and recovery rates. However, when we substitute GDP growth for our primary bond default rate variable, the multivariate results are quite meaningful, albeit with a lower explanatory power than the one obtained with the BDR variable.

32 These results are based upon the simulation engine presented in detail in Resti (2002).

${ }^{33}$ Based on Standard \& Poor's rating classes, the composition can be summarized as follows: AAA: 8.0\%; AA: $8.0 \%$; A: $9.0 \%$; BBB: $23.0 \%$, BB: $40.0 \%$; B 9.0\%; CCC 3.0\%. The use of data on rated bonds would probably have introduced a severe bias, as the average credit quality of bonds, in the aggregate, tends to be better than that of bank loans.

${ }^{34}$ Standard \& Poor's (2001). We are aware that bond data and through-the-cycle ratings are not fully apt to represent the behaviour of bank loans; yet, we believe that such limitations are outweighed by the benefits of using public, certified, long-term data as those supplied by S\&P.
} 
to the empirical default rates recorded by S\&P and the loans' LGD (given a 50\% LGD, a $100 €$ default means a $50 €$ loss).

Capital requirements are measured according to the "corporate exposures" curve presented in Basel Committee on Bank Supervision (2001a, the so-called "consultative package two"); the new curve for corporate exposures, circulated in November 2001 (Basel Committee on Bank Supervision, 2001b), is used as well.

Figure 5: a simulation exercise on the pro-cyclical effects of the PD/LGD correlation

(a) Background: indicators of the credit quality cycle

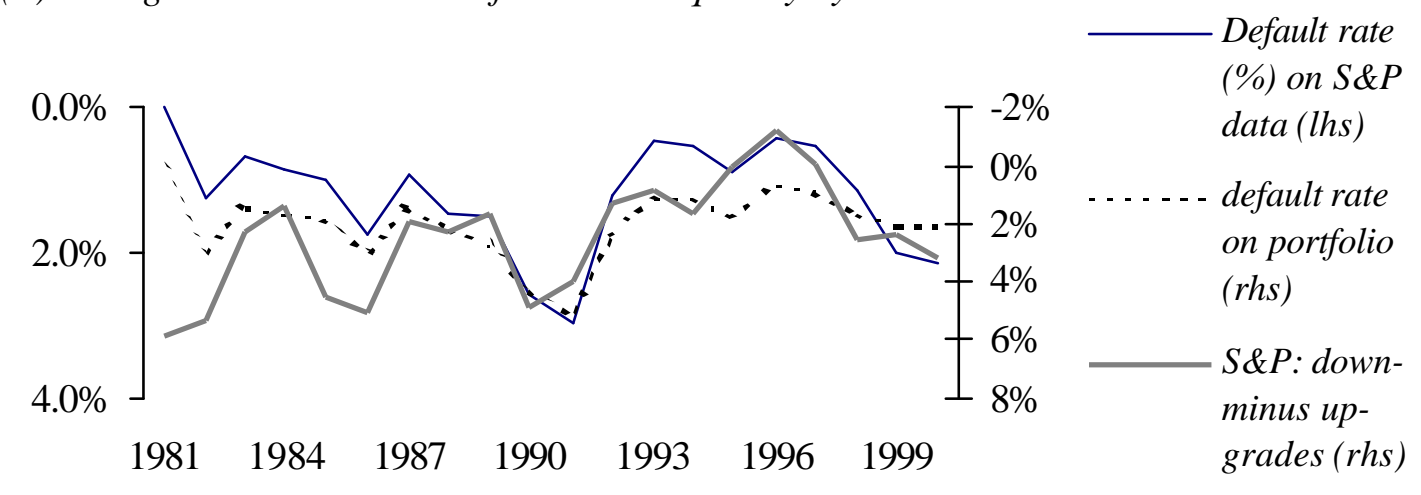

(b) Simulation results for corporate loans: change in portfolio size

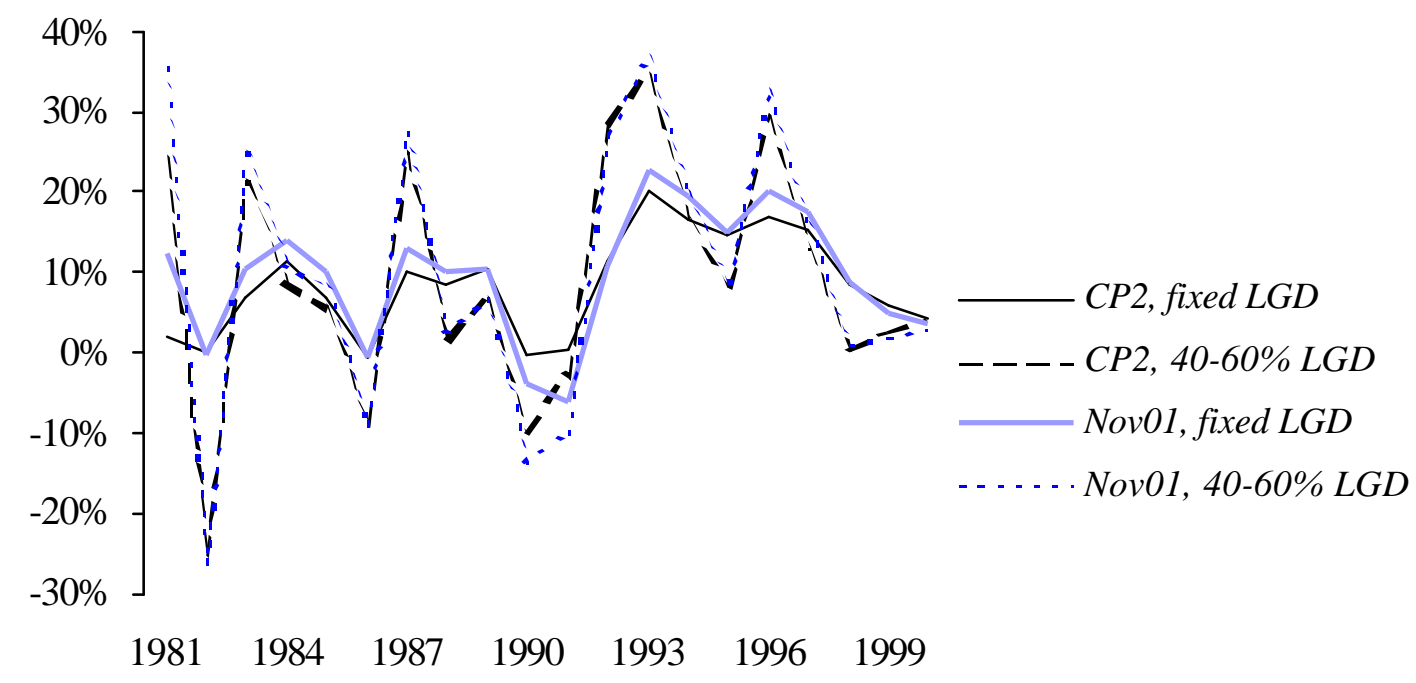

Our simulation contrasts two different scenarios. In the former, a standard 50\% LGD is used for all loans (as in the "foundation" approach, where severities on unsecured, senior loans are fixed by regulators). In the latter, LGDs fluctuate between $60 \%$ (in high default years) and 
$40 \%$ (in low default years) ${ }^{35}$. Note that, as mentioned above, a similar setting may become realistic when banks move to the advanced IRB approach and start using their own LGD estimates.

We now turn to Figure 5, where simulation results are summarized:

1. The first panel (a) reports three indicators of the credit quality cycle: the default rate measured by Standard and Poor's on US bonds, the default rate experienced by the bank (given its portfolio mix) and the "net downgrade rate" (downgrades minus upgrades, over total outstanding issues). Note that scales are inverted, since an increase in these variables means that the cycle is getting worse. As can be seen, default and downgrade risks fluctuate up and down in the Eighties, hit a low in the early Nineties, then keep improving in the following years, although they worsen again towards the end of the decade.

2. The second panel (b) reports a measure of credit availability: the percent change in the loan portfolio made possible (or necessary) by the evolution of the capital ratios. When the margin income exceeds credit losses, and/or capital requirements decrease because of a favourable evolution in the quality mix of the loans, the bank's capital grows beyond the minimum requirements: we then compute by how much the loan portfolio could be enlarged; similarly, when capital charges increase more than net profits would allow, we estimate the reduction in loans needed to comply with Basel ratios.

Two results are worth mentioning. First, the procyclicality effect is driven more by upand downgrades, rather than by default rates; in other words, adjustments in credit supply needed to comply with capital requirements seem to respond mainly to changes in the structure of weighted assets, and only to a minor extent to actual credit losses. However this is not true in 1991 when the default rate is exceptionally high. Second, when we let LGDs free to fluctuate with default rates, the procyclicality effect increases significantly, both for the CP2 curve and November 2001 curve $^{36}$. Moreover, one could also show that bank spreads, too, would become more volatile (since revisions in short-term LGD estimates would be factored into loan prices) ${ }^{37}$.

\footnotetext{
${ }^{35}$ We used a second-degree polynomial to model the link between LGDs and empirical default rates, so that LGD is $50 \%$ when default rates are at their 20-year average (2\%), LGD is $60 \%$ when default rates hit their 20-year maximum (5\%) and LGD is $40 \%$ when default rates hit their 20 -year low (0\%).

${ }^{36}$ Surprisingly enough, the new weight curve for corporate loans proposed in Basel Committee on Banking Supervision (2001b), although it considerably reduces capital requirements in a static sense, would not ease the procyclicality effect, at least for loan portfolios like our simulated one. The reason for this rather counter-intuitive behaviour is that under the November 2001 curve, although the increase in weights when moving to an AA to a
} 
Thus, if a positive correlation between default and recovery risk (like that in Section 3 for US bonds), were to be confirmed by bank data, the procyclicality effects might be even more severe than expected. Of course, one might object that the bank in our simulation behaves in a somewhat myopic way, and that regulation should encourage "advanced" IRB systems to use long-term average recovery rates (instead of revising them yearly, according to short-term signals like the current default rate). However, while the use of long-term LGDs would make procyclicality effects less marked, it would also force banks to maintain a less updated picture of their risks, thereby trading stability for precision.

\section{Concluding remarks}

This paper analyzed the link between aggregate default probabilities and the loss given default on bank loans and corporate bonds, both from a theoretical and an empirical standpoint, and tried to spot its implications for various credit VaR models as well as for bank regulation and procyclicality effects. As far as the theoretical aspects are concerned, most of the literature on credit risk management models and tools treats the recovery rate variable as a function of historic average default recovery rates (conditioned perhaps on seniority and collateral factors), but in almost all cases as independent of expected or actual default rates. To us, this appears to be a rather simplistic and perhaps unrealistic approach: empirical evidence as well as simulations results suggest more care in dealing with this fundamental aspect of credit risk modeling.

We saw in Section II how simulation results for expected and unexpected losses may change under three different recovery rate scenarios. We first assumed that recovery is deterministic (fixed), then that recovery rates are stochastic yet uncorrelated with the probability of default, and finally that they are stochastic and negatively correlated with default probabilities. Introducing this third hypothesis prompts a significant increase $(30 \%)$ both in risk measures (unexpected losses) and in the expected cost of defaults. The assessment and measurement of the PD/LGD correlation (if any) therefore turns out to be a pivotal empirical issue.

To this aim, in Section III we examined the recovery rates on corporate bond defaults, over the period 1982-2000, by means of rather straightforward statistical models. These models

CCC rated loan is lower, smaller quality changes can bring about a sharper rise in capital requirements than they did under the CP2 function. This would slightly enhance procyclicality in "normal times" (when most rating changes affect the middle part of the rating scale); however, the new curve would probably smooth cyclical effects under extreme scenarios, when a large part of bank borrowers moves to the bottom grades of the rating scale.

${ }^{37}$ See Resti (2002) for details. 
assign a key role to the supply of defaulted paper (default rates) and explain a substantial proportion of the variance in bond recovery rates aggregated across all seniority and collateral levels.

Our results have important implications for just about all portfolio credit risk models, for markets which depend on recovery rates as a key variable (e.g., securitizations, credit derivatives, etc.), and for the current debate on the revised BIS guidelines for capital requirements on bank credit assets. Namely, in Section IV, we have shown that the link between LGD and PD will possibly bring about a sharp increase in the "procyclicality" effects of the new Basel Accord, when individual banks are free to use their own severity estimates; actually, if banks tend to revise such estimates upwards in "bad" times, bank capital and credit supply might behave even more pro-cyclically than expected. 


\section{References}

Altman, Edward I., 1989, "Measuring Corporate Bond Mortality and Performance", Journal of Finance 44, 909-922.

Altman, Edward I., 2001, "Altman High Yield Bond and Default Study", Salomon Smith Barney, U.S. Fixed Income High Yield Report, July.

Altman, Edward I., 1991, Distressed Securities, Irwin Publishing (reprinted by Beard Books, 1999).

Altman Edward I., and P. Arman, 2002, "Defaults and Returns in the High Yield Bond Market: Analysis Through 2001," NYU Salomon Center Working Paper, January.

Altman, Edward I. and Brooks Brady, 2002, "Explaining Aggregate Recovery Rates on Corporate Bond Defaults", NYU Salomon Center, Working Paper Series, January.

Altman, Edward I. and Jason Pompeii, 2002, "The Performance of Defaulted Bonds and Bank Loans: 1987-2001”, NYU Salomon Center Working Paper Series, January.

Altman, Edward I. and Vellore M. Kishore, 1996, "Almost Everything You Wanted to Know About Recoveries on Defaulted Bonds", Financial Analysts Journal, November/December.

Altman, Edward I., Andrea Resti, and Andrea Sironi, 2001, Analyzing and Explaining Default Recovery Rates, a Report submitted to ISDA, London, January.

Basel Committee on Banking Supervision, 1999, Credit Risk Modeling: Current Practices and Applications,. Bank for International Settlements, June.

Basel Committee on Banking Supervision, 2001a, "The Basel Capital Accord", Consultative Paper, Bank for International Settlements, January.

Basel Committee on Banking Supervision, 2001b, "Potential Modifications to the Committee's Proposals", Bank for International Settlements, Basel, November.

Black, Fischer and John C. Cox, 1976, "Valuing Corporate Securities: Some Effects of Bond Indenture Provisions", Journal of Finance, 31, 351-367.

Cambridge Associates, LLC, 2001, U.S. Distressed Company Investing, Cambridge, MA.

Carey, Mark and Michael Gordy, 2001, "Systematic Risk in Recoveries on Defaulted Debt," Unpublished Working Paper presented at the 2001, Financial Management Association Meetings, Toronto, October 20.

Credit Suisse Financial Products, 1997, CreditRisk+. A Credit Risk Management Framework, Technical Document.

Crouhy, Michel, Dan Galai and Robert Mark, 2000, "A Comparative Analysis of Current Credit Risk Models", Journal of Banking \& Finance, 24, 59-117.

Duffie, Darrell and Kenneth J. Singleton, 1999, "Modeling the Term Structures of Defaultable Bonds", Review of Financial Studies, 12, 687-720.

Duffie, Darrell, 1998, "Defaultable Term Structure Models with Fractional Recovery of Par", Graduate School of Business, Stanford University.

Duffee, Gregory R., 1999, "Estimating the Price of Default Risk", Review of Financial Studies, Spring, 12(1), 197-225. 
Eom, Young Ho, Jean Helwege and Jing-zhi Huang, 2001, "Structural Models of Corporate Bond Pricing: An Empirical Analysis", mimeo.

Finger, Chris, 1999, "Conditional Approaches for CreditMetrics ${ }^{\circledR}$ Portfolio Distributions”, CreditMetrics ${ }^{\circledR}$ Monitor, April.

FITCH, 1997, “Syndicated Bank Loan Recovery Study,” R. Grossman, M. Brennan and Vento, October 22.

FITCH, 2001, "Bank Loan and Bond Recovery Study: 1997-2001,” S. O’Shea, S. Bonelli and R. Grossman, March 19.

Fons, Jerome, 1987, "The Default Premium and Corporate Bond Experience," Journal of Finance, vol. 42, No. 1.

Fridson, Martin, Christopher Garman and Chen Wu, "Real Interest Rates and Default Rates on High Yield Bonds," Journal of Fixed Income, September 1977.

Frye, John, 2000a, “Collateral Damage”, Risk, April, 91-94.

Frye, John, 2000b, "Collateral Damage Detected", Federal Reserve Bank of Chicago, Working Paper, Emerging Issues Series, October, 1-14.

Frye, John, 2000c, “Depressing Recoveries”, Risk, November.

Geske, Robert, 1977, "The Valuation of Corporate Liabilities as Compound Options", Journal of Financial and Quantitative Analysis, 12, 541-552.

Gordy, Michael, 2000a, "A Comparative Anatomy of Credit Risk Models", Journal of Banking and Finance, January, 119-149.

Gordy, Michael B., 2000b, "Credit VaR Models and Risk-Bucket Capital Rules: A Reconciliation," Working Paper, Federal Reserve Board, March.

Gupton, Greg M., Christopher C. Finger and Mickey Bhatia, 1997, "CreditMetrics - Technical Document", (New York, J.P.Morgan).

Gupton, Greg M., Daniel Gates and Lea V. Carty, 2000, "Bank Loan Loss Given Default", Moody's Investors Service, Global Credit Research, November.

Hamilton, David T., Greg M. Gupton and Alexandra Berthault, 2001, "Default and Recovery Rates of Corporate Bond Issuers: 2000”, Moody's Investors Service, February.

$\mathrm{Hu}$, Yen-Ting, and William Perraudin, 2002, "The Dependence of Recovery Rates and Defaults", BirkBeck College, mimeo, February.

Hull, John and Alan White, 1995, "The Impact of Default Risk on the Prices of Options and Other Derivative Securities", Journal of Banking and Finance, 19, 299-322.

Jarrow, Robert A. and Stuart M. Turnbull, 1995, "Pricing Derivatives on Financial Securities Subject to Credit Risk", Journal of Finance 50, 53-86.

Jarrow, Robert A., 2001, "Default Parameter Estimation Using Market Prices", Financial Analysts Journal, Vol. 57, No. 5, pp. 75-92.

Jarrow, Robert A., David Lando, and Stuart M. Turnbull, 1997, “A Markov Model for the Term Structure of Credit Risk Spreads", Review of Financial Studies, 10, 481-523.

Jarrow, Robert, 2000, "Estimating Recovery Rates and (Pseudo) Default Probabilities Implicit in Debt and Equity Prices," Working Paper, Cornell. 
Jokivuolle, Esa and Samu Peura, 2000, “A Model for Estimating Recovery Rates and Collateral Haircuts for Bank Loans", Bank of Finland Discussion Papers February.

Jones, E., S. Mason and E. Rosenfeld, 1984, "Contingent Claims Analysis of Corporate Capital Structures: An Empirical Investigation”, Journal of Finance, 39, 611-627.

Kim I.J., K. Ramaswamy, S. Sundaresan, 1993, "Does Default Risk in Coupons Affect the Valuation of Corporate Bonds? A Contingent Claims Model", Financial Management, 22, No. 3, 117-131.

Lando, David, 1998, “On Cox Processes and Credit Risky Securities”, Review of Derivatives Research, 2, 99-120.

Litterman, Robert and T. Iben, 1991, "Corporate Bond Valuation and the Term Structure of Credit Spreads", Financial Analysts Journal, Spring, 52-64.

Longstaff, Francis A., and Eduardo S. Schwartz, 1995, "A Simple Approach to Valuing Risky Fixed and Floating Rate Debt", Journal of Finance, 50, 789-819.

Madan, Dileep and Haluk Unal, 2001, "Pricing the Risk of Recovery in Default with APR Valuation," Journal of Banking and Finance, forthcoming.

Madan, Dileep, and Haluk Unal, 1995, "Pricing the Risks of Default", University of Maryland Working Paper, forthcoming in the Journal of Banking and Finance, 2002.

Marullo-Reedtz Paolo, 2000, Misurazione e gestione del rischio di credito: la risposta delle banche italiane alle innovazioni normative, mimeo, Associazione per lo sviluppo degli studi di Banca e Borsa, Milano.

McQuown J. (1993) A Comment On Market vs. Accounting Based Measures of Default Risk, mimeo, KMV Corporation.

Merton, Robert C., 1974, "On the Pricing of Corporate Debt: The Risk Structure of Interest Rates”, Journal of Finance, 2, 449-471.

Moody's, 2001, "Default and Recovery Rates of Corporate Bond Issuers: 2000", D. Hamilton, G. Gupta and A. Berthault, February.

Nielsen, Lars T., Jesus Saà-Requejo, and Pedro Santa-Clara, 1993, "Default Risk and Interest Rate Risk: The Term Structure of Default Spreads", Working Paper, INSEAD.

Resti, Andrea, 2002, The New Basel Capital Accord: Structure, possible Changes, micro- and macroeconomic Effects, Centre for European Policy Studies, Brussels.

Saikat, Nandi, 1998, "Valuation Models for Default-Risky Securities: An Overview", Federal Reserve Bank of Atlanta, Economic Review, Fourth Quarter.

Saunders, Anthony, and Linda Allen, 2002, Credit Risk Measurement: New Approaches to Value at Risk and other Paradigms, $2^{\text {nd }}$ edition, John Wiley \& Sons, New York.

Saunders, Anthony, 1999, Credit Risk Measurement: New Approaches to Value at Risk and other Paradigms, John Wiley \& Sons, New York.

Standard \& Poor's, 2000, "Recoveries on Defaulted Bonds Tied to Seniority Ratings," L. Brand and R. Behar, CreditWeek, February.

Standard \& Poor's, 2001, Rating Performance 2000. Default, Transitions, Recovery and Spreads, Standard \& Poor's, January. 
Van de Castle, Karen and David Keisman, 2000, "Suddenly Structure Mattered: Insights into Recoveries of Defaulted Loans", Standard \& Poor's Corporate Ratings, May 24.

Vasicek, Oldrich A., 1984, Credit Valuation, KMV Corporation, March.

Wilson, Thomas C., 1997a, "Portfolio Credit Risk (I)", Risk, Vol. 10, No. 9, 111-117.

Wilson, Thomas C., 1997b, "Portfolio Credit Risk (II)”, Risk, Vol. 10, No. 10, 56-61.

Wilson, Thomas C., 1998, "Portfolio Credit Risk", Federal Reserve Board of New York, Economic Policy Review, October, 71-82.

Zhou, Chunsheng, 2001, “The Term Structure of Credit Spreads with Jump Risk", Journal of Banking \& Finance 25, 2015-204. 